\title{
Distribution and Chemical Analysis of Pharmaceuticals and Personal Care Products (PPCPs) in the Environmental Systems: A Review
}

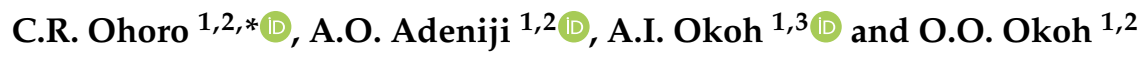 \\ 1 SAMRC Microbial Water Quality Monitoring Centre, University of Fort Hare, Alice 5700, South Africa \\ Department of Chemistry, University of Fort Hare, Alice 5700, South Africa \\ 3 Applied and Environmental Microbiology Research Group, Department of Biochemistry and Microbiology, \\ University of Fort Hare, Alice 5700, South Africa \\ * Correspondence: greatnemerem@yahoo.co.uk
}

Received: 9 June 2019; Accepted: 31 July 2019; Published: 21 August 2019

\begin{abstract}
PPCPs are found almost everywhere in the environment especially at an alarming rate and at very low concentration in the aquatic systems. Many methods-including pressurized hot water extraction (PHWE), pressurized liquid extraction (PLE), ultrasound-assisted extraction (UAE), and micro-assisted extraction (MAE) - have been employed for their extraction from both surface waters and biota. Solid-phase extraction (SPE) proved to be the best extraction method for these polar, non-volatile, and thermally unstable compounds in water. However, ultrasonic extraction works better for their isolation from sediment because it is cheap and consumes less solvent, even though SPE is preferred as a clean-up method for sediment samples. PPCPs are in groups of-acidic (e.g., diclofenac, ibuprofen, naproxen), neutral (e.g., caffeine, carbamazepine, fluoxetine), and basic pharmaceuticals, as well as antibiotics and estrogens amongst others. PPCPs which are present in trace levels $(\mathrm{ng} / \mathrm{L}$ ) are more often determined by liquid chromatography-mass spectrometry (LC-MS), gas chromatography-mass spectrometry (GC-MS), and high-performance liquid chromatography-ultraviolent (HPLC-UV). Of these, LC-MS and LC-MS-MS are mostly employed for the analysis of this class of compounds, though not without a draw-back of matrix effect. GC-MS and GC-MS-MS are considered as alternative cost-effective methods that can also give better results after derivatization.
\end{abstract}

Keywords: pharmaceuticals and personal care products; endocrine disruptors; ultrasonic-assisted extraction; liquid chromatography mass spectrometry; solid-phase extraction

\section{Introduction}

Pharmaceuticals and personal care products (PPCPs) are over the counter therapeutic and veterinary drugs, ranging from analgesics and antibiotics to contraceptives and lipid regulators in addition to active ingredients in soaps, detergents, musk, bleaches, dyes, deodorants, shampoos, perfumes and hair cream, and skin and dental care products. Continuous introduction of these products to the environment, given their multiple disperse mechanisms and pharmacological activities may result in detrimental impacts on wildlife and humans [1-6]. Similarly, Ebele et al. [7] defined pharmaceuticals as inappropriate use of drugs and veterinary therapeutic medicines which are employed to check or cure animal and human diseases, whereas personal care products (PCPs) are utilized mostly to enhance the standard of every-day life. PPCPs are grouped as pharmaceuticals, and personal care products (PCPs). PPCPs comprise of chemicals that are biologically energetic, hormone-disruptive, and toxic [8]. Pharmaceuticals include antihyperlipidermis, stimulants (caffeine), analgelsics 
(ibuprofen, diclofenac, paracetamol, ketoprofen, naproxen), psychiatric drugs (carbamazepine, primidone), antibiotics (sulfamethoxazole, chloramphenicol, trimothoprin, ciprofloxacin), lipid regulators (gemfibrozil, bezafibrate, propranolol, atenolol, metoprolol), and antipyretic; while PCPs include synthetic musk fragrance (nitropolycyclic musks), antimicrobial compounds (triclosan), UV blockers (methylbenzylidene camphor), antioxidants and preservatives (phenols and p-hydroxybenzoic acid (parabens)) and insect repellents ( $N, N$-diethyl-m-toluamide (DEET) [9], hormones (estrone E1, estradiol E2, ethynlestradiol EE2) [10]. PPCPs frequently detected in the environment include antibiotics, analgesics, steroids, antidepressants, antipyretics, stimulants, antimicrobials, disinfectants, fragrances, and cosmetics. This is based on their daily usage and consumption [11]. Yang et al. [12] in their research in advanced wastewater reclamation plant in Gwinelett County detected sulfamethoxazole, primidone, caffeine, and DEET frequently in the final effluent at concentrations of 10-100 ng/L. Moreover, Vlachagrammi and Athanasios [13] stated that steroids and non-prescription drugs are the most frequently detected. These include $N, N$-diethyltoluamide, caffeine, triclosan, copostanol, cholesterol, tri(2-chloroethyl)phosphate, and 4-nonylphenol.

In the last decade, environmental pollution of aquatic systems by PPCPs has been of increasing anxiety [14,15]. The rise in fate, effect and probability of exposure to danger by PPCPs has suggested the demand for dependable analytical method for quantification in diverse matrices. PPCPs have predominantly been detected at very low concentrations, although some are comparatively incessant owing to their constant usage and delivery into aquatic environment. As a result, aquatic organisms may possibly be subject to risk of these contaminants at a sub-lethal concentration over the time of their life phase [15]. According to Archer et al. [16], the existence and fortune of PPCPs in the surroundings are of growing prevalent significance as a result of their ubiquitous identity and reported consequence on wildlife, ecosystem, and potentially, humans. Increase in agricultural productivity has steered to increase the use of pesticides, of which most are persistent [17]. PPCPs have been marked the most recurring identified organic contaminants in the aquatic surroundings. Notable concentrations have been discovered in environmental water at a range from $\mathrm{ng} / \mathrm{L}$ to hundreds of $\mu \mathrm{g} / \mathrm{L}[18-24]$ and $\mathrm{ng} / \mathrm{L}$ in municipal wastewater [25] and yet it is unclear whether this is posing danger to humans and wildlife anthropologically [16]. Besides, there is no regulation in place for this class of organic contaminants at the moment [26].

PPCPs are bioactive, they do not solubilize with ease or evaporate at ordinary temperatures or pressures, and so can enter with ease into the soil and water through sewage, bio-solids, and irrigation. They are harmful to both humans and animals. There is also indication that PPCPs are related to a number of ecological harm such as retarded maturity in fish and also in their metamorphosis [27]. Though the concentrations of single pharmaceuticals shown in evaluated water bodies globally are small and may be incapable of causing harm to the health of humans, constant vulnerability to a combination of such substances may cause disorder to the stability in the human body and intensify a high risk opposition to antibiotics, thereby constituting menace to the well-being of existing organisms; a burden that numerous scientists are presently exploring in other to find solution to it [5,28-31]. Some likely effects of PPCPs on living organisms have been reported, they include: increased feminization and masculinization of fish populations [5,32], nervous system damage, cancer, disruption of immune system, and the reproductive disorders [33]. They have been enlisted as "emerging contaminants" $[11,26]$ and also as endocrine disruptors (EDCs) because they are capable of mimicking or altering various vertebrate endocrine systems pathways [34-36].

Garrison et al. [37] reported that the first discovery and publication that addressed pharmaceuticals in wastewater and effluents was given by US EPA, following this, Kummerer [38] stated that there is wide gap of data documentation on existence, out-turn, or action of PPCPs and their metabolites in waters. Management of pharmaceuticals and the treatment associated with them is not as inflexible in African countries compared to developed countries, and the present wastewater treatment systems are not intended for managing pharmaceuticals as pollutants [32]. Effluents of urban wastewater and receiving waters had been shown to contain numerous pharmaceuticals at low concentrations 
in developed countries where carbamazepine recorded the utmost concentration of $2.33 \mathrm{ng} / \mathrm{mL}$ in England [39-45] 0.21-2.62 ng/mL in Spain [30] 2.01 to $16.1 \mathrm{ng} / \mathrm{mL}$ in Saudi Arabia [46] and $<1 \mathrm{ng} / \mathrm{mL}$ in Ireland [41]. Pharmaceuticals have been considered as emerging contaminants within the environment mostly as a result of their increasing usage, inappropriate discarding of unutilized or drugs that have expired and ineffectiveness of wastewater treatment plants (WWTP) to eliminate these contaminants completely $[8,47,48]$. Consequently, they find their ways into ground, marine, and drinking waters $[4,44,49]$. Their occurrences in the environment have been associated with harmful effects on the healthiness of humans and animals. Such effects include nervous system damage, cancer, disruption of immune system, and the reproductive disorders [33]. They have been enlisted as "emerging contaminants" [11,26] and also as endocrine disruptors (EDCs) because they are capable of mimicking or altering various vertebrate endocrine system pathways [34-36].

EDC is defined by the USEPA as an exotic medium that inhibits the synthesis, release, binding, transport, action, or annihilation of natural hormones in the body with the purpose of accountability for the conservation of reproduction, development, homeostasis, and/or behaviour [50]. Synthetic compounds largely regularly incriminated as EDCs involve pesticides, PPCPs, and industrial by-products [16]. PPCPs have various effects on aquatic organisms [51,52], deadly toxicity inclusive at incredibly elevated concentrations and changes in bacterial communities in aquatic ecosystems [53-55] with special significance on transience. Although, a number of outstanding sub-lethal effects-such as histological changes, behavioural effects, biochemical responses, and gene regulation-can arise at low concentrations [56]. Studies have shown the feminization of masculine fish and ubiquitous existence of anti-androgenic ligands in UK Rivers which collect effluents from linked WWTWs [57-59] also reported the distortion of male reproductive system in immature male alligators in diverse lakes located in Florida, USA owing to these pollutants [59]. Together with the distress about the prevalent disorder of human reproductive systems tending to several environmental unfriendly consequences such as breast cancer, ovarian cancer, and reduced sperm quality, global concerns were expressed concerning the probable clever disruption of the endocrine systems of wildlife and humans in the organizational window through development $[33,60]$.

In Europe, there has been ban on chemicals commonly used in the production of PCPs which include phthalates and parabens. Rise in prescription for aging people with one chronic disease or the other; or youths having certain health challenges including neurobehavioural developmental disorders, has led to increased absorption of drugs in the USA [8]. Richardson et al. [61] reported that China was the world largest producer of pharmaceuticals in 2003 with annual production of 28,000 of penicillin ( $60 \%$ of world total production), 10,000 tonnes of terramycin ( $65 \%$ of world total production); and also ranked first among nations for the production of doxycycline hydrochloride and cephalosporins. Similarly, China is known for their legendary in the use of antibiotics, consuming about $70 \%$ of antibiotics used nationwide. Furthermore, Mutiyar and Mittal [62] reported that India is among the top five countries producing PPCPs. They are found increasingly in their surface waters notwithstanding their scarcity of water. Owing to this, humans and aquatic biota are exposed continually to these contaminants. Disappointingly, no needful action has been taken in this region to arrest the situation [62].

Examples of different kinds of PPCPs include:

\subsection{Carbamazepine}

Carbamazepine is among the class of antiepileptic/psychiatric drugs used to control seizure, mental illness and depression [63]. It is an anthropogenic marker [64] and has been considered as wastewater indicator in aquatic environment owing to its persistence $[65,66]$. According to Faigile and Feldman [67], 72\% of CBZ oral dose are excreted in urine and $28 \%$ in faeces. It has been the most frequently detected pharmaceutical residues in water bodies [68], terrestrial environment [62], and WWTPs, in which little or no removal from wastewater has been widely reported, thus making it very important [68]. 


\subsection{Erythromycin}

Detection of this antibiotics in the environment has been of major concern because of its ability to alter the microbial structure and function, and also influence the development of antimicrobial resistance $[69,70]$. Its mechanism of action is through binding to the $50 \mathrm{~S}$ subunit of the bacteria ribosome to impede protein synthesis [71,72]. It inhibits a definite cardiac potassium channel which appears to play a major role in cardiac rhythm regulation in the early embryo [73]. Erythromycin A, a 14 membered ring is the first macrolide, a class of antibiotics to be used to treat human infections [74]. Erythromycin has been reported in Asia, North America, Europe, China, and the UK and limited data has been reported in Africa, Eastern Europe, Central and South America [75].

\subsection{Parabens}

They are alkyl esters of p-hydroxybenzoic acid and are used as antimicrobial preservatives in consumer products including PPCPs with methylparabens, ethylparabens, and propylparabens being the major ones found in food stuffs [76] as a result of their high solubility in water, stability, low production cost, and relative safety when used [77-79]. Studies have shown that cosmetic products are its main source of exposure to human [78,79]. Its environmental pollution is of concern having been detected in human breast tumour as reported by Darbre et al. [80], sperm DNA damage in men [81], currency bills and sanitary wipes [82], WWTP [83,84], PCP [85,86].

\subsection{DEET}

DEET was developed in 1946 in the USA to guard the troops deployed from mosquito bites and related diseases [87,88], and thereafter made available to the public in 1957 as active ingredient of insect repellents. This can be found in spray, lotion for skin, in clothes and nets to guard against diseases transferred by vector bites and in prevalent areas [87,89] and antifeedant [90]. Merel [91] reviewed that DEET is one of the most commonly detected organic chemical contaminants in water.

\subsection{Triclosan}

Triclosan has since 1968 being used in consumer products such as antiseptic, disinfectants, cosmetics, preservatives in clinical settings, and also incorporated in medical devices, plastic materials, kitchen utensils and textiles as reported by Bedoux [92]. It has been detected in fish [93], human samples (urine, breast milk, and serum), because of its high lipophilicity, and also in sewage effluent, river, surface water, and sediment [94]. It is highly hydrophobic, biodegradable, photo-unstable and reactive towards chlorine and ozone.

\subsection{Caffeine}

Caffeine is one of the world's most consumed stimulants. Its source is mostly from beverage and food especially coffee [95]. The leaves can be seen as herbicides as its plant prevents the growth of other surrounding plants. It has been used as insect repellent because of its bitter taste, and as toxicant at high dose [96]. It can also increase pollination to enhance reproduction [97]. There has been a report on its cardiovascular, behavioural, and reproductive effects [98].

This paper therefore seeks to review the characteristics, distribution, mobility, and physicochemical properties of PPCPs in environmental matrices, human samples and biota; and also to assess the available techniques for their analysis.

\section{Characteristics of PPCPs}

There has not been proper report about environmental risk of exposure to PPCPs, however, they possess the characteristics of chemicals that give a major concern with adverse effects on aquatic lives. These characteristics include persistence, bioaccumulation, and toxicity. Some PPCPs such as 
steroids, non-steroidal pharmaceuticals and a number of PCPs are endocrine disrupting [7]. Many PPCPs are persistent and hence, have been potentially risky when discharged into the environment [16].

\subsection{Persistence}

They are not easily eliminated from the typical water treatment operations, thereby posing threat to aquatic lives exposed to them [99]. Occurrence, treatment, and toxicological relevance of EDCs and pharmaceuticals in water [100]. Houtman [101] and Daughton and Ternes [11] also added that some of the PPCPs have restricted lifetime in the environment and are not necessarily persistent but are repeatedly used and released to the environment even after the process of biodegradation, photodegradation, and sorption; and so classified them as "pseudo-persistent". Several of these PPCPs have been reported to be tenacious during wastewater treatment thus, constituting hazard when discharged into the environmental waters $[47,67,102]$. Similarly, Vieno et al. [103] stated that biodegradation, sorption, photodegradation, and sedimentation can also remove PPCPs in the aquatic environment. Consequently, Lam et al. [104] reported that half-lives of PPCPs ranges from 1 day with acetaminophen, to 82 days with carbamazepine in sun-drenched microcosms of bare pond water and normal autoclaved water, and that tested pharmaceuticals did not breakdown in the gloomy control microcosms, thereby signifying that photo degradation, not biodegradation, may possibly be a restricting factor in the perseverance of PPCPs.

\subsection{Bioaccumulation}

There is still lack of comprehension of kismet and bioaccumulation of PPCPs in the environment and their outturn on ecosystem function [105,106]. Bioaccumulation of PPCPs is affected by $\mathrm{pH}$, presence of surfactants, and also suspended solids [107-109]. Shraim et al. [46] made an inference that not many health threats can be related to long term vulnerability to a single drug but with disclosure to a large number of pharmaceuticals, their metabolites, and transformation products, even at small concentrations. Muir et al. [110] repeatedly detected carbamazepine, metoprolol, and sulfamethoxazole in water but not in fish plasma indicating swift biotransformation.

\subsection{Toxicological Effects and Health Risks}

Antipyrine is one of pharmaceutical active compounds easily detected in aquatic organisms, capable of causing organ deterioration because of its cytotoxicity towards mucosa and lungs on long term exposure [111]. Though pharmaceuticals are not as tenacious as other organic compounds, they have been found in concentration ranging from $\mathrm{mg} / \mathrm{L}$ to $\mathrm{ng} / \mathrm{L}$ depending on the compounds, part of the environment in which they are determined, and degree of application of the substances in the study area. Low concentrations of these contaminants have proven to have potentials to induce unfavourable effect on lives in the ecosystem. The established risks include the development of microbial opposition to antibiotics on exposure to hormones [32]. Similarly, Wang et al. [112] and Snyder [100] reported that PPCPs contain various groups of compounds capable of generating potential risk on aquatic lives by inducing fish's nephridial tissue necrosis, affecting the growth of algae and duckweed, intensifying the microbial resistance to antibiotics. They further stated that the most poisonous endpoint is not curative endpoint, but relatively the carcinogenic side effect and also life-threatening toxicity at an exorbitant temperature and alteration in bacterial communities in an aquatic ecosystem [53-55]. Although, at low temperature, behavioural effects, biochemical reactions, and gene management can also arise [56].

Pharmaceuticals being biologically active may have effect on non-target organisms at low concentration in terrestrial and aquatic environments. Chronic toxicity and possible insidious environmental effects are barely known, though acute toxicity effect on non-target organisms have been studied. Acute toxicity to aquatic organisms is improbable to occur as the measured concentration in the terrestrial environment is 100-1000 times higher than the residues found in aquatic environment. It is only salient in case of spills [113] or specifically for organisms inherent in effluent-dominated system [107]. PPCPs are not likely to cause acute toxicology since they appear in low concentration. 
The ecotoxicity, bioavailability, and duration of exposure to non-target organisms is a guide to evaluate the strength of these compounds in the environment [114], and so may be ignored in natural aquatic habitat [115]. Furthermore, life-cycle analysis is scarcely reported except for $17 \alpha$-ethynlestrdiol [116] which has shown some estrogenic effect in reproduction on fish at very low concentration [117]. There is need for concern about feminization and masculinization of hormone and xenoestrogens, synergistic toxicity from complex mixtures at low concentration, possible invention of opposition strains in natural populations and other probable interests for human health; though the environmental toxicology is not clear [67]. Dussault et al. [118] investigated on four PPCPs which are carbamazepine, atorvastatin, $17 \alpha$-ethynlestrdiol and triclosan and deduced afterwards that triclosan was the most toxic followed by $17 \alpha$-ethynlestrdiol, atorvastatin, and carbamazepine in that order. Similarly, Delorenzo and Flaming [119], also carried out an investigation which showed that of six PPCPs (triclosan, fluoxetine, simvastin, clofibric, carbamazepine, and diclofenac), only triclosan produced toxicity at usual environmental concentration.

Rise in the levels of PPCPs such as penicillin and zithromax in the receiving waterbodies may eventually result in the increase in resistance to antibiotics $[69,120]$. There is no available data from risk assessment and ecotoxicology of most occurring emerging contaminants, so it is difficult to envisage their health implication on humans, terrestrial and aquatic organisms, and ecosystem. Furthermore, PPCPs occur in a very low concentration which is incapable to cause acute effect. However, health effect as a result of long-term exposure cannot be avoided [13]. Similarly, Becker and Stefenakis [121] reviewed that it is difficult to evaluate the exposure effects of PPCPs in human health, following that PPCPs are detected at sub-therapeutic concentrations. Most times, they appear in a mixture with other compounds making it impossible to fix which among the contaminants is the problem especially when chemicals form a compound and also because the persistence of PCPs is comparatively short and may not be detected.

\section{Distribution and Mobility}

Owing to the low volatility of PPCPs, their distribution will occur via water bodies and food chain dispersion than through the atmospheric environment. The polar and non-volatile nature of a huge number of them will as well limit their disappearance from the aquatic media. Volume of PPCPs produced will also to a great level dictate the extent of their distribution in the environment $[7,11,122]$. These classes of chemicals have great tendency for long range transport in the environment, subject to their physical and chemical properties, as well as the characteristics of the receiving environment. PPCPs are usually by adsorption found in sludge samples, and subsequently in the environment when the sludge is used as fertilizer on farmlands [123]. The presence of these chemicals in the groundwater, possibly due to leaching from biosolids applied to farmlands, or treated wastewater employed for irrigation has been reported [124-126]. This can in turn be taken up by plants, which now becomes a major way of human exposure by dietary intake $[127,128]$. They can also enter surface water through runoff from contaminated farmlands, biosolids or from landfills, and as a result presents a risk to both aquatic and public lives [7,11,13].

Generally, the movement of PPCPs across different environmental media is dependent on the sorption behaviour of the compound of interest in plants, soil, and the water-sediment system [129]. Sediment is considered the primary sink for the organic pollutants by sorption [130] and they may eventually be released back to the aquatic environment after several accumulations in the sediment. PPCPs such as sulfamethoxazole, carbamazepine, triclosan, and ciprofloxacin are reportedly more persistent in the sediment than water [131,132]. Continuous release of these organic chemicals from sediments to overlying water is therefore possible, and this may adversely affect the benthic organisms which are continuously exposed to PPCPs found in the sediments, interstitial and overlying waters [7,133]. 


\section{Physicochemical Properties of PPCPs}

\subsection{Temperature, Polarity, and Stability to Heat}

They are moderately polar, non-volatile and not stable to heat. It is therefore difficult to use GC for their analysis without prior derivatization [15,134].

4.2. $p H$

Pharmaceuticals vary from acidic (carboxylic acids, e.g., diclofenac, bezafibrate) to basic (secondary amines e.g., paroxetine, bisoprolol). Overall methodologies discriminating in opposition to interferences should be established to investigate the major environmentally pertinent pharmaceuticals [135].

\subsection{Solubility}

Majority of the pharmaceuticals are extremely soluble in water and consequently retain solubility in the aqueous phase while the ones with low solubility remain insoluble with solid materials in wastewater $([102,136,137]$. They dissolve readily in aqueous form and do not vanish at ordinary temperature or pressure, and so find their way into the water bodies through treated sludge (biosolids), sewage, and irrigation with domesticated waters $[138,139]$.

\subsection{Volatility}

Volatilization is the interchange of contaminants between water and gas phases. Generally, PPCPs have low volatility [119]. They are either non-volatile or semi-volatile, only few of them are volatile [15]. Their runoff from the aquatic sphere being principally spread in the course of aqueous transport and food chain is being prevented by their decreased volatility [11].

\subsection{Sources of PPCPs in the Environment}

Most of the components of PPCPs are man-made and are gotten from human activities. They do not occur in nature except few of them such as caffeine which is of plant origin, produced by over 60 plants. PPCPs get to marine environment through wastewater and polluted surface water, septic tanks, livestock breeding, landfills, and sewer leakage [137,140]. Suppes et al. [141] reported that PPCPs can be found in swimming pools through fill water and human impact like urine, sweat, swim wear, and body surface. They enter the environment through humans, veterinary consumption, excretion, bathing, discarding of unutilized products, flushed down toilets, wastewater treatment plants, surface runoffs and leaching $[16,142,143]$, residues and wastes from hospitals, wastes from pharmaceutical industries, use of illegal and veterinary drugs and agribusiness $[29,37,40,144]$. Although, they can also be detected at non-point sources especially in surface waters at small concentrations as ng to $\mu \mathrm{g} / \mathrm{L}$ [11]. It is however uncertain if this low concentration can cause unsatisfactory physiological consequence in wildlife and humans [16].

\section{Sample Collection, Storage, and Preparation}

Sample preparation performs an important task in analytical methodology. Most analytical instruments are inadequate to manage matrices directly, and some kinds of pre-treatment are needed to extract and isolate the analytes [145]. Sample preparation is taken to be the major contaminating step of analysis, since it normally needs the utilization of organic solvents [146].

According to [147], appropriate collection and preservative procedures are required to make certain sample probity and retain the steadiness of the analytes pending investigation. Data from inappropriately collected and preserved samples bring about misconception of the existence and outcome of the compounds being investigated. Emerging contaminants such as PPCPs and steroids mostly exist in drinking and surface water at ng/L levels. Amber bottles were discovered to have minimal consequence on concentrations of target analytes, whereas elevated density polyethylene 
bottles can greatly interfere. Preserving with sodium azide at $4{ }^{\circ} \mathrm{C}$ proved to enhance the steadiness of the target analytes in their study. Hence, amber bottles were used with sodium azide and ascorbic acid which preserved all the analytes at $4{ }^{\circ} \mathrm{C}$ for 28 days, except two were considered the most appropriate. Englert [148] also reiterated the need for sample collection using amber glass container in accordance with standard practices.

For aqueous samples, water that flows effortlessly is collected as the grab sample. Acidic and basic samples are collected in $1 \mathrm{~L}$ bottles. The bottles should not be rinsed before sample collection. Where residual chlorine is found, $10 \mathrm{mg}$ sodium thiosulfate per litre of water is added. Ascorbic acid can be used as preservative for some pharmaceuticals, however, it has not been assessed for all of them. If aqueous sample is not extracted within $48 \mathrm{~h}$ of collection, $\mathrm{pH}$ should be adjusted to 5.0 to 9.0 with $\mathrm{NaOH}$ or $\mathrm{H}_{2} \mathrm{SO}_{4}$ solution. For solid samples, grab sampling is more frequently employed. Adequate amount of $10 \mathrm{~g}$ solids is collected and maintained in the dark $<6{ }^{\circ} \mathrm{C}$ from collection point to the laboratory and then stored in the dark less than $-10^{\circ} \mathrm{C}$ until analysis. Extraction from aqueous, bio-solids, mixed phase, and solid samples should commence within 7 days $(48 \mathrm{~h}$ is strongly recommended) as some may degrade promptly. The extract should be analysed within 40 days of extraction. Freezing of samples is recommended to reduce degradation, and extraction should be carried out within $48 \mathrm{~h}$ of defrosting [148]. Standard methods however suggested that extracts should be analysed as soon as possible, not exceeding 28 days after preparation [149].

Ort et al. [150] stated that errors in sampling can lead to over interpretation of constant data and eventually, incorrect deductions. On the determination of sewer type, catchment size, sampling structure, substance of scrutiny, and reliability of analytical method, preventable sampling relics can vary from 'insignificant' to $100 \%$ or more for various compounds even in the same study. Sampling errors and biases can be minimized significantly by selecting fittingly sampling mode and frequency.

\section{Environmental Matrices of PPCPs}

\subsection{Wastewater, Sewage, and Sludge}

Sewage treatment plants (STPs) is the major source of PPCPs in the environment [11]. Antibiotics is the main abundant group of pharmaceuticals found in STP of China having concentration up to 1730-7910 ng/L for influent sample and ND-94960 ng/L for effluent samples as reported by Liu and Wong [10]. Some of the greatest analytical conflicts to a thorough analysis of sewage sludge require managing the big negative surface charges and interstitial scope that gives multiple active sites for charged compounds, and the clean-up step for removing the magnitude materials (e.g., surfactants, fats, proteins) that are co-extracted with the pharmaceuticals [151]. During wastewater treatment, alteration of PPCPs possibly will take place based on the physicochemical properties of the compounds and the state of the WWT. PPCPs may possibly be totally ruined, or partly modified to metabolites or in a few occasions left unaffected during the process [151]. It is essential to know that the degradation or elimination of the parent analytes during WWT does not certainly denote the elimination of toxicity, it is anticipated that a significant number of alteration products whose toxicity and tenacity are unknown might still be found in the last effluent together with the receiving water bodies [109].

\subsection{Surface Water and Sediment}

PPCPs, after they are ejected, washed off from human body, or directly released to the sewerage system, go into surface water majorly through improper treated wastewater effluent. Most of them are regularly found in river water with concentrations of single $\mu \mathrm{g} \mathrm{L}^{-1}$ and their levels depends majorly on the level of water dilution as a result of rainfall [152]. Various groups of PPCPs were investigated for their existence in surface waters. The degree of their concentrations in the aqueous environment is dependent on a variety of parameters such as efficiency of treatment of wastewater, meteorological conditions (mainly rainfall), proximity to wastewater plants, and geographical position [106,153-163]. 
PPCPs may go through diverse environmental processes, majorly photolysis and adsorption by sediments. A good number of antimicrobial media, such as triclosan, seem to be adsorbed and trapped in the pores of sediments and subsequently decrease its solubility. The course of adsorption can be influenced by $\mathrm{pH}$ [164]. Elimination of PPCPs can be achieved by adsorption from water bodies, though, PPCPs in the sediments (being their sink) may possibly be discharged back into the aquatic environment [165]. Aqueous photolysis is a possible way of removing tetracycline, although the process could still be improved by high $\mathrm{pH}$ [166]. Nonetheless, these contaminants are usually found in surface water sediments at a level much lower than in sludge samples [167].

\subsection{Soil and Drinking Water}

PPCPs can be introduced into soil by applying livestock wastes as fertilizers, sludge land application or landfill, and domesticated water irrigation. Contamination in soil may possibly be built-up in plants or drift through soil wholly or altered and get to ground water, finally leading to contamination of the source of drinking water. Veterinary antibiotics subsisted in the soil from organic vegetables farmland fertilized with livestock wastes from Tianjin in concentrations up to $2683 \mathrm{ng} / \mathrm{g}(\mathrm{dw})$ [168]. Lin and Gan [164] discovered some drug variety, like diclofenac and ibuprofen that showed inadequate adsorption with persistence under anaerobic condition. The leaching of PPCPs may possibly be influenced by chemical characteristics (such as pKa values), salinity of the irrigation water and soil properties (e.g., organic matter and clay content) [169,170]. For instance, Qiao [171] detected four kinds of PPCPs approximately $1 \mathrm{ng} / \mathrm{L}$ in drinking water in South China.

\subsection{Biota}

Global studies have associated the disclosure to effluents of WWTP having PPCPs with harmful influence on the marine organisms' reproduction [172]. A study also showed bioaccumulation of a combination of estrogenic pollutants in fish tissues, thus leading to the incorporation of vitellogenin and most likely advancing to feminization of wild fish inhabiting UK Rivers [172]. A national pilot research in the US, evaluated build-up of PPCPs in fish sampled from five effluent-controlled rivers which receives express release from wastewater treatment in Florida, Pennsylvania, Illinois, Arizona, and Texas. The research showed the existence of galaxolide and tonalide in fish fillets at each effluent-dominated site with maximal concentrations ranging from 300 to $2100 \mathrm{ng} / \mathrm{L}$ and $21-290 \mathrm{ng} / \mathrm{L}$ in that order. The pharmaceuticals discovered both in liver and fillets comprise; norfluoxetine, diphenhydramine, diltiazem, sertraline, fluoxetine, gemfibrozil, carbamazepine, with sertraline the most plentiful at maximal concentrations of $19 \mathrm{ng} / \mathrm{L}$ in fillet and $545 \mathrm{ng} / \mathrm{L}$ in liver tissue [173]. Also, the harmful decrease in the population of vulture in Pakistan has been partly accredited to dietary vulnerability of vultures to diclofenac-treated livestock. Particularly, the diclofenac was discovered in the kidneys of all 25 vultures that died of renal breakdown at the concentrations of $0.051-0.643 \mu \mathrm{g} / \mathrm{g}$ [174]. Li et al. [175] also discovered 13 antibiotics in majority of the investigated hydrophyte samples (aquatic plants) such as Ceratophyllum demersum (Cer), Salvinia natans (Sal), Hydrocharis dubia (Hyd); 4 crustacean species including river snail (Viva parus), crab (Eriocheir sinensis), lobster (Palinuridae), shrimps (Macrobrachium nipponense); and 7 fish species: yellow catfish (Pelteobagrus fluvidraco), loach (Misgurnus anguillicaudatus), and topmouth gudgeon (Pseudorasbora parva), among others from Baiyangdian Lake, China. The respective concentrations of antibiotics in Sal, Hyd, and Cer were $1769 \mu \mathrm{g} / \mathrm{kg}, 129 \mu \mathrm{g} / \mathrm{kg}$, and $253 \mu \mathrm{g} / \mathrm{kg}$ [175]. Other researches have also reported the detection of ciprofloxacin concentrations in the aquatic plant (Echinodorus amazonicus) as high as $795 \mu \mathrm{g} / \mathrm{kg}[45,176]$.

Liu et al. [177] also showed concentrations of steroid estrogens at $11.3 \mathrm{ng} / \mathrm{g}$ dry weight $(\mathrm{dw})$ in species of undomesticated fish such as silvery minnow, crucian carp, and carp from Dianchi Lake in Southern China. Liver showed the largest estrogen build-up, followed by gills and muscle. Also, Ali et al. [178] detected caffeine. Methylparaben and carbamazepine in concentration 41.3, 44.3, and $1.7 \mathrm{ng} / \mathrm{g}$ (on a dry weight basis) respectively. Presently, little is investigated regarding the PPCPs levels in biota generally. Not many studies have evaluated PPCP residues in mammals, fish, and 
birds. There is also a paucity of information on the possible trophic amplification of these analytes or the effect of prenatal exposure on the probable conveyance of PPCPs to eggs of birds and other nascent wildlife [7]. Some PPCPs have revealed to build-up in fish tissue sampled from surface waters accepting discharges of effluent [173-179]. PPCPs have been determined in diverse tissues of fish such as blood plasma, brain, fillet, and liver [18,111,173-184]. For example, the pharmaceuticals sertraline (STL), fluoxetine, carbamazepine (CBZ), diphenhydramine (DPH), gemfibrozil, and diltiazem, and PCPs triclosan, tonalide (AHTN), and galaxolide (HHCB), were currently shown in fish from five US rivers in the US EPA's national pilot research of PPCPs in fish tissues [182]. Prior PPCPs studies have determined synthetic musk [185], alkylphenols and their monoethoxylates [186], and triclosan and one of its metabolites [185] in the German Environment Specimen Bank (GESB), from fish tissue samples collected from 1994 to 2003.

\section{Extraction Techniques}

Vogues in isolation of analytes include reduced solvent consumption, improved extraction throughout, increased recoveries, and better reproducibility [146,187]. According to Nieto et al. [188] and Pérez-Lemus et al. [189], several extraction techniques have been developed and used in investigating PPCPs in environmental matrices like sewage sludge. These methods are based on liquid partitioning [190], conflict extraction and chromatographic analysis; they include Soxhlet, ultrasonication (USE) [191-193], and supercritical fluid (SFE) extraction methods [194]. Recently, environmentally friendly extraction methods like microwave-assisted extraction (MAE) $[2,195,196]$ and pressurized liquid extraction (PLE) $[186,197,198]$ have become prominent and apparent as effective means of increasing automation, reducing extraction time and minimizing the amount of organic solvent [199]. Concerning modern extraction methods (e.g., PLE and MAE), their small extraction times (5-45 min), less solvent consumption, reduced cost of equipment and simplicity of operation are their major advantages over classical methods. The extraction and analytical techniques are summarised in Table 1.

\subsection{Solid-Phase Extraction (SPE)}

SPE is the major routinely utilised method [200-204] for extracting pharmaceuticals from water samples. Oasis HLB, with its hydrophilic-lipophilic balance, is mostly utilised for pharmaceuticals extraction with a broad range of polarities and $\mathrm{pH}$ values $[205,206]$. Oasis MCX, a mixed-mode resilient cation-exchanger, consequently gives both ion-exchange and reversed-phase retention and can adsorb neutral, polar, non-polar, and cationic compounds synchronously from aqueous media. MCX has been outstandingly used to extract an extensive range of pharmaceuticals and synthetic hormones from water matrices $[152,207,208]$. Many researchers extract PPCPs from aqueous sample using SPE except for few such as Yu et al. [209], who used the same SPE for the extraction of the analytes of interest from sludge as shown in Table 1. The use of SPE for aqueous sample is in accordance with EPA [148].

Similarly, work done by Shraim et al. [46] showed that Oasis MCX cartridges which was used for extraction of PPCPs can retain acid, base and neutral drugs in solution depending on the functional group(s) it possesses and on the $\mathrm{pH}$ of the solution, and has shown to give high overall recoveries. In the study, drugs were divided into two groups: "acidic and neutrals" and "basics", this was to improve the sensitivity of the MS detector and to avoid any complication during analysis $[41,210]$.

\subsection{Pressure Liquid Extraction (PLE)}

PLE utilizes pressure and temperature without extending to evaluative time [211] and has more superiority over traditional methods (such as Soxhlet and USE). Study conducted by Gobel et al. [197] also preferred PLE over USE in extraction of several antibiotics including sulphonamides (sulfapyridine, sulfamethoxazole), macrolides (azithromycin, roxithromycin, clarithromycin), and trimethroprim, in dried samples of activated and digested sewage sludge. These advantages include good recoveries [190], reduced extraction time, reduced solvent utilization and extra extract filtration, 
achieved by adding inactive material to the extraction [197,212]. PLE also has an advantage of not being restricted to extraction solvents that can absorb microwaves over newer technique like MAE. However, PLE has got some shortcomings of having selectivity not as high as might be needed towards analytes throughout extraction causing many interferents to be co-extracted, based on the kind of sample. Also, the analytes are occasionally diluted, mostly when an elevated number of revolutions is used [213]. To prevent this dilution by the interferents, SPE using Oasis HLB, Oasis MCX, and Strata-X cartridges, being the most common technique for clean-up should be utilized [190,197,214], with several sorbents. SPE also pre-concentrates aside cleaning of analytes. Gel-permeation chromatography (GPC) is another technique used for clean-up [215].

\subsection{Ultrasound Assisted Extraction (UAE)}

UAE is a cheap and effective substitute to conventional extraction methods (e.g., Soxhlet that needs extensive processing time of $4-24 \mathrm{~h}$ and high volume of solvent). It also extracts thermal unstable analytes that may possibly be transformed in the operational conditions of Soxhlet. In addition, cavitation expanses the polarity of extractants and analytes, hence improving extraction. The method can be utilised with whichever solvent. Extraction of analytes is mainly dependent on the solvent's polarity, the nature and uniformity of the sample, the ultrasound frequency and the sonication time [33].

Employment of ultrasounds is a likely means for extraction effectiveness enhancement. Ultrasonic field cites numerous occurrences that may definitely influence the operation kinetics: decrease in viscosity, micro-floats and in the case of appropriately described parameters, also cavitation and rise of processed medium temperature. Hence, USE finds its wide utilization for isolation of several organic substances [216-223] though not reproducible [224]. The ultrasound activity is indivisibly linked with heat liberation in the investigated medium. The occurrences accountable for an addition of temperature in the managed material are: absorption of ultrasound energy friction of boundary and interface surfaces, and, in the case of high extremities, cavitation [225]. Nearly $75 \%$ of acoustic energy conveyed by ultrasonic converter may possibly be eventually modified into thermal energy of a system sorted out [226]. The relevance of UAE to the investigation of emerging contaminants in environmental solid matrices (e.g., sediment, soil, and sludge) has gained attention, as revealed in the several studies depending on UAE published articles in the recent time. Techniques for sludge samples are not as many as those for soil or sediment because of the complication of sludge. Parabens and UV filters have been effectively extracted from sediment and soil by means of UAE in small columns with acetonitrile or ethyl acetate, correspondingly, as extraction solvent, and SPE as a clean-up step [227,228]. A broad variety of analytes have been researched by means of ultrasound assisted extraction (USE). For example, applying it to pharmaceuticals and EDCs $[191,229,230]$, antibiotics [231], and pharmaceuticals and personal care products (PPCPs) have been reported. However, equivalent solvents to those employed in Soxhlet are used during USE, both the extraction solvent volume and the time of extraction are decreased to $4-60 \mathrm{~mL}$ and $10-30 \mathrm{~min}$, respectively [232]. It is an adopted method with acetonitrile for solid samples according to EPA [148].

\subsection{Pressurized Hot Water Extraction (PHWE)}

PHWE is similar to PLE but employs the use of water as the extraction solvent at elevated temperature and lower pressure [233,234]. The report in the literature contains only few examples of PHWE pertaining to emerging and persistent organic compounds in a diversity of matrices [235]. The major determinant that influences extraction effectiveness during PHWE is temperature; since high temperatures, low surface tensions, and low viscosities are achieved at high diffusions. Also, the compounds' vapour pressure rises at elevated temperatures and hence, thermal desorption from the solid matrix takes place. Although, hydrolysis, degradation or oxidation of the target compounds can as well take place at elevated temperatures. $\mathrm{pH}$ of the water phase is another variable worked on during PHWE when working on analytes with acid-base properties, given that more of the charged part solubilizes in the water-phase and improved extraction effectiveness can be gained under those 
conditions. Other variables like those considered when discussing PLE-e.g., the number of cycles and the flush volume-are as well developed during PHWE [236]. PHWE has been successfully utilised for the analysis of non-steroidal anti-inflammatory drugs (NSAIDs), diclofenac, ketoprofen, naproxen, and ibuprofen [236].

\subsection{Dispersive Liquid-Liquid Micro-Extraction (DLLME)}

DLLME comprises of extraction with a water-immiscible solvent and a disperser that are promptly injected into the aqueous solution consisting the analytes under scrutiny, and leads to the generation of an unclear solution, separated subsequently by centrifugation. DLLME has gained unique awareness for the reason that its short extraction times, clarity, and high enrichment factors (EFs) for low water volumes. The application of sonication to this method has brought about increase in its significance in recent years because ultrasound-assisted dispersive liquid-liquid micro-extraction UA-DLLME gives a surged rate of mass transfer of analytes from the aqueous phase to the filmy extracting droplets.

The recovery of analytes in UA-DLLME is dependent on various factors, like the amount of sample, the extraction and disperser solvents and their volumes, the ionic strength or the $\mathrm{pH}$. All extraction solvents employed in the investigation of emerging contaminants were chlorinated hydrocarbons (e.g., dichloromethane, chloroform, and carbon tetrachloride). Concerning the disperser, methanol, and acetone were the solvents mainly generally utilized. In the case of PCPs, UA-DLLME was useful for the concurrent determination of parabens and bisphenols [237].

\subsection{Microwave Assisted Extraction (MAE)}

MAE, also known as microwave-assisted solvent extraction (MASE) is one of the green solvent extraction methods which have been developed to eliminate the obvious pollution of releasing solvent into the environment which is applicable to traditional solvent extraction and technique for the valid investigation of emerging organic contaminants, validating its addition regarding regulatory environmental field [183]. It is a method of employing microwave energy to heat sample solution so as to separate analytes from the sample matrix into the solvent [145]. MAE is simple to apply and rapid, and gives good extraction effectiveness equivalent to or greater than those acquired with classical methods (i.e., Soxhlet or LLE) and other more current techniques (i.e., SFE or PLE) [238]. MAE can be static, a process whereby the sample is submerged in the extraction solvent and illuminated by microwave, an aliquot of the extract is aspirated by a pump for additional treatment subsequently; or dynamic (DMAE), a process whereby the extraction solvent constantly passes through the sample. DMAE can be either closed (performing an extraction in a recirculation system, the aliquot of the extract is aspirated at completion subsequently) or open (having the sample constantly exposed to fresh solvent, the extracted analytes are subsequently transferred to next analytical procedure).

MAE can also be focused microwave-assisted Soxhlet extraction (FMASE) (static-dynamic MAE) which is dependent on the same principle as conventional Soxhlet extraction but employing microwave as auxiliary energy to accelerate the extraction process [145]. Among the major precedence of MAE, is the substantial decrease of extraction time and solvent consumption, and the option to carry out multiple extractions, increasing the sample all through. The suitable cost of the equipment should also be considered. The optimization of MAE situations is rather simple because of the small number of significant parameters (i.e., time, nature of the solvent, matrix moisture, power, and temperature in closed vessels). Other current applications of MAE reported novel concentration procedures depending on the utilization of ionic liquid (IL)-based surfactants and focused MAE for the pre-concentration and extraction from sediments of organic contaminants e.g., PAHs, alkylphenols, and parabens. Although microwave extraction is a routine method for solid samples, original micro-extraction approaches, indicating the utilization of surfactants and ILs, were currently conveyed for the pretreatment of water samples [238].

The use of MAE has stimulated growing curiosity, and has been generally employed in analytical chemistry because of its many superiorities. It has been implemented to resistant matrices such as 
drugs and pollutants in animal and human tissues, and to matrices collected at polluted sites where selection or characterization is needed for the reason of successive or on-going restorative work [239]. MAE, which can be performed with open or closed vessels, utilizes microwave energy to heat the sample-solvent mixture. The solvents for extraction accessible for MAE are normally restricted to those that take in microwaves (solvents with permanent dipole), though the utilization of solvent mixtures with and without dipoles proffers MAE applications to a variation of possible solvent mixtures [232].

From a green chemistry perspective, besides the cost and decreasing the energy input, the major advantages of MAE comprises of: significant reduction of solvent needed hence, reducing waste production; enhancement of extraction all through; and, decrease of sample amount needed [195,240]. Extraction time is much lower when implementing MAE, mostly as a result of the variation in heating implementation used by the microwave method and normal heating. With the later, a fixed period is required in heating the vessel before transferring heat to the solution; whereas the solution is heated directly with microwaves, so maintaining the temperature slope to the least and increasing the heating speed. Furthermore, MAE enables for obvious decrease inorganic solvent utilization and the probability of concurrently running multiple samples. MAE accordingly largely satisfies the minimal standard needed for modern sample preparation methods. However, it is a very desirable substitute to more conventional methods [146,201,232,241].

\subsection{Supercrtical Fluid Extraction (SFE)}

Here there is loading of the sample in elevated pressure vessel and extraction is done with supercritical fluid, most routinely carbon dioxide [242], with methanol included to the modifier when polar compounds are extracted $[243,244]$ at the pressure $150-450$ bar and temperature of $40-150{ }^{\circ} \mathrm{C}$. The collection of analytes is done in a little volume of solvent or onto solid phase trap which is rinsed with solvent in a successive step. Extraction time for SFE is 10-60 min extracting 1-5 g of sample with 2-5 mL solvent usage for solid trap and 5-20 mL liquid. Advantages of SFE include fast extraction, minimum solvent volumes, elevated temperature, adequately selected towards martrix interferences, no clean up or filtration required, and extracts are concentrated in an automated system. Its major drawbacks are the numerous parameters to optimise [242].

\subsection{Soxhlet Extraction (SE)}

With the use of Soxhlet extraction, the solid sample is put in a glass fibre thimble and by employing a Soxhlet extractor, the vapour of solvents frequently seeps the sample. The extraction time is $3-48 \mathrm{~h}$, extracting 1-30 g of sample with 100-500 ML of solvent. SE has an advantage of no filtration needed but its limitations are long extraction time, large solvent consumption and needed clean-up step. It also wastes cooling water and electric energy [242], and labour intensive. Notwithstanding, it has been utilized for extraction of organic compound from solid matrices owing to its elevated extraction effectiveness [245-248]. It has been utilized in compound like triclosan [249]. The extraction is investigated in three stages: rinsing, boiling, and solvent recovery [250]. There is not much work done on extracting PPCPs using Soxhlet extractor.

\section{Clean Up and Pre-Concentration}

After extraction, clean-up is occasionally expedient to minimize the limit of detection (LOD) and to reduce the interferences. Many techniques which are in use for the clean-up of PPCPs include gel permeation chromatography (GPC), columns for purifying extracts from PLE [215], and SPE for both clean-up and pre-concentration with the use of $C_{18}$ and Oasis HLB as sorbents [190,197]. The sorbents like ENV+ Oasis HLB, Strata-X, Lichro lut $\mathrm{C}_{18}$ and Lichor EN have been utilised for clean-up and pre-concentration of pharmaceuticals in water [134]. 


\section{Chromatographic Analysis and Detection}

9.1. Gas Chromatography-Mass Spectrometry and Gas Chromatography-Mass Spectrometry/Mass Spectrometry (GC-MS and GC-MS $S^{2}$

GC-MS and GC-MS² remain the predominantly utilised techniques because of their higher level of sensitivity, broad accessibility in environmental laboratories, and the well-accepted electron-impact (EI) MS libraries. With suitable derivatization, GC-MS or GC-MS ${ }^{2}$ is a sensitive, cost-effective method suitable for regular analysis. It is also worth noting that GC-MS or GC-MS ${ }^{2}$ does not suffer much from the matrix effect that is often observed in electrospray ionization (ESI)-based LC-MS or LC-MS ${ }^{2}$ analysis [251]. However, because of the poor volatility of certain compounds, derivatization steps which focused on producing additional volatile products are needed to enhance the sensitivity of the following GC analysis. Consequently, the merits of superior sensitivity are from time to time largely nullified by losing of sample in the extra manipulation [251,252]. Excluding some neutral drugs and fragrance constituents (musks), most PPCPs are polar, non-volatile, and thermally unstable compounds that are inappropriate for GC separation. Derivatization of hydroxyl- and carboxyl-groups preliminary to GC-MS or GC-MS ${ }^{2}$ analysis of PPCPs has hence become a needful step. Derivatization is normally carried out by using organic reactions (e.g., silylation, methylation, and acetylation) following analytes extractions and clean up from the sample matrix. Although, the results may be affected by individual experimental parameters (e.g., reaction time, temperature, and different reactivity agents utilised). Derivatization agents are normally preferred following their reaction with the analytes or the steadiness of their yield so that hydrolysis will not likely happen [253].

\subsection{Liquid Chromatography-Mass Spectrometry and Liquid Chromatography-Mass Spectrometry/Mass Spectrometry (LC-MS and LC-MS ${ }^{2}$ )}

LC-MS has earned vogue in the recent years, because of the sensitivity, sturdiness, and simplicity of utilisation allowed by the current API interfaces, such as atmospheric pressure chemical ionization (APCI) and electrospray (ESI) [254]. Incorporated with a novel inception of MS equipment (single quadrupole, ion-trap, triple quadrupole), LC-MS and LC-MS-MS have not just been prevalent, they are also regular techniques for respective classes of EDCs, such as natural and synthetic steroids, alkylphenolic compounds, and bisphenolic compounds.

LC-MS is an appropriate method given that no derivatization process is needed. It allows carrying out detection and quantification in one distinct step. Although, the matrix effect originated by the exorbitant concentration of matrix ionisable constituents-e.g., salts, ion-paring agents, natural organic matter, non-target pollutants - that can meddle with the ionization processes, mainly when ESI interface is employed is one of the focal disadvantages of the investigation of trace organics in composite samples by LC-MS/MS [255,256]. This reaction can be more substantial in intricate environmental samples, like sewage sludge, and it might lead to a clue prevention or improvement, resulting to little sensitivity and unreliable conclusions [255,256]. Accordingly, to make certain the accuracy of the performed technique, the assessment of the matrix effect is generally regarded in the reported literature as a bit of the method validation [232]. Furthermore, LC-MS ${ }^{2}$ has been more routinely employed in pharmaceutical investigation for the reason of its elevated sensitivity and its potential to establish compounds in comparison with usual LC with ultraviolet (UV) or fluorimetric detection. LC-MS ${ }^{2}$ permits isolation and identification of compounds which have dissimilar product ions though equal molecular mass even if they co-elute. $\mathrm{MS}^{2}$ detection is consequently for enlarged analytical sensitivity and selectivity in composite samples like wastewaters [257].

\subsection{Capillary Electrophoresis (CE)}

Opportunely, capillary electrophoresis has proven to be cheap, effective, and speedy separation method that has been broadly related in investigation of pharmaceuticals [258]. Analytes that are difficult to isolate by LC are frequently rectified using CE for the reason of its being selective by 
additives, $\mathrm{pH}$ tuning, and buffer concentration [259]. Sensitivity restrictions generated by short light path lengths and sample injection volumes in nanoliter may possibly be controlled by on-line pre-treatment techniques like stacking and sweeping [260,261], or off-line sample pre-treatment proficiency such as solid-phase micro-extraction (SPME), SPE, and LLE. Consequently, some CE methods have been shown to determine PPCPs in natural water [262], drinking water [263], river water [264], tap water [265], and stagnant water [266]. The major frequently used methods are GC and high-performance liquid chromatography (HPLC) with mass spectrometry (MS) detection [23,142,267]. Though, when chromatographic techniques are engaged, intricate sample pre-treatment is required and defective isolation for the comparatively polar compounds is a hitch. Furthermore, the excessive investigation cost renders these techniques less popular in standard research. CE has been told to be an inexpensive, effective, and swift separation method that has been extensively related in pharmaceutical investigations [258,268].

\subsection{High Performance Liquid Chromatography-Mass Spectrometry (HPLC-MS)}

A technique based on separation and detection was established by Andreozzi et al. [269]. The utilisation of MS as the detector vehemently restricts the option of a mobile phase. The mobile phase should be volatile, ideally not simply ionisable, and repress the interaction of analytes and silanol groups, which leads to peak tailing. Alternatively, the mobile phase should react with analytes to yield charged ions. Moreover, a separation of such chemically and structurally dissimilar compounds as b-blockers and fluoroquinolones needs a stationary phase which is both inactive (highly deactivated) and shows adequate retention time.

\section{Detection of PPCPs}

Analysis for trace EDCs has been influenced by two instrumentation techniques for the past few decades-GC with several types of detectors, including flame ionization detector (FID), electron capture detector (ECD), and MS [270-272]; or the LC with a broad diversity of detectors, such as MS, diode array (DAD), and fluorescence detectors [273,274]. Every instrumentation technique has its own superiority and their way of measuring EDCs is dependent on the chemical and physical properties of the analytes being investigated. Though, employing these instrumental methods has definite drawbacks given as inability to attain needed sensitivity and having deficient selectivity in several occasions. Accordingly, a significant switch was detected when more selective, seasoned and sensitive detector systems such as ion trap MS, triple quadrupole MS, orbitrap MS and time-of-flight MS was chosen by researchers. GC-MS and LC-MS-MS remains the desired instrumental methods for the investigation of EDCs, especially for pharmaceuticals, alkylphenol compounds, and estrogenic hormones in environmental samples [275].

Identification is an age-old complex and strenuous procedure due to the scope of materials possibly seen in clean water [149]. Mass spectrometric (MS) detection is currently desired because of its authentication influence and measurement to the small concentration of these pollutants in sewage sludge. Albeit single-quadrupole instruments were utilized successfully whilst LC-MS methods were initially developed to investigate residues of PPCPs [211], alternative composite mass analyzer (e.g., triple-quadrupole analyzers (QqQs)) are mostly used so the target analytes can be detected unambiguously $[189,190]$. Tandem mass spectrometry (MS/MS), such as triple-quadrupole (QqQ) and quadrupole time-of-flight $(\mathrm{QqQ})$ are time and again used for investigation of pharmaceuticals in environmental matrices with the integration of PLE, LC, and MS or tandem MS (MS²). Limits of detection (LODs) at small $\mu \mathrm{g} / \mathrm{kg}$ degree of dry weight (d.w.) can be acquired $[276,277]$ in agreement with Diaz-Cruz et al. [186] who asserted that LODs obtained with LC-MS ${ }^{2}$ techniques, working in SRM mode, have been lower than those reached with GC-MS, but stated that they will also require more versatile and less complicated sample preparation. 
Table 1. Extraction techniques of various pharmaceuticals and personal care products.

\begin{tabular}{|c|c|c|c|c|c|}
\hline Analyte & Sample Matrix & Extraction Mode & Analysis & Concentration & Reference \\
\hline \multirow[t]{3}{*}{ Caffeine } & Influent & $\mathrm{b}$ & $\mathrm{m}$ & $25,578 \mathrm{ng} / \mathrm{L}$ & [24] \\
\hline & Effluent & $\mathrm{b}$ & $\mathrm{m}$ & 115.1 & [24] \\
\hline & River & $\mathrm{b}$ & $\mathrm{m}$ & $34-238$ & [24] \\
\hline \multirow[t]{4}{*}{ Carbamazepine } & Influent & c & $\mathrm{P}$ & $2.1 \mu \mathrm{g} / \mathrm{L}$ & [278] \\
\hline & Effluent & c & $\mathrm{P}$ & $0.39 \mu \mathrm{g} / \mathrm{L}$ & [270] \\
\hline & Activated sludge & c & $\mathrm{P}$ & $0.76 \mu \mathrm{g} / \mathrm{L}$ & [270] \\
\hline & Surface water & c & $\mathrm{p}$ & $28.3 \mathrm{ng} / \mathrm{L}$ mean conc & [267] \\
\hline \multirow[t]{4}{*}{ Sulfamethaxazole } & Influent & $\mathrm{b}$ & $\mathrm{m}$ & 356 ng/L & [24] \\
\hline & Effluent & $\mathrm{b}$ & $\mathrm{m}$ & $22 \mathrm{ng} / \mathrm{L}$ & [24] \\
\hline & Intermediate & $\mathrm{b}$ & $\mathrm{m}$ & $57 \mathrm{ng} / \mathrm{L}$ & [24] \\
\hline & River1 & $\mathrm{b}$ & $\mathrm{m}$ & $25-58$ ng/L & [24] \\
\hline \multirow[t]{3}{*}{ Triclosan } & Influent & c & $\mathrm{p}$ & $1.8 \mu \mathrm{g} / \mathrm{L}$ & [272] \\
\hline & Effluent & c & $\mathrm{p}$ & $0.05 \mu \mathrm{g} / \mathrm{L}$ & [270] \\
\hline & Activated sludge & c & $\mathrm{p}$ & $0.09 \mu \mathrm{g} / \mathrm{L}$ & [272] \\
\hline \multirow[t]{10}{*}{ Naproxen } & Biosoild & e & o & $470 \mathrm{ng} / \mathrm{dw}$ & [273] \\
\hline & Influent & c & $\mathrm{p}$ & $14 \mu \mathrm{g} / \mathrm{L}$ & [272] \\
\hline & Effluent & c & $\mathrm{p}$ & $0.08 \mu \mathrm{g} / \mathrm{L}$ & [272] \\
\hline & Activated sludge & c & $\mathrm{p}$ & $1.8 \mu \mathrm{g} / \mathrm{L}$ & [272] \\
\hline & Influent & $\mathrm{b}$ & $\mathrm{m}$ & $863 \mathrm{ng} / \mathrm{L}$ & [24] \\
\hline & Effluent & $\mathrm{b}$ & $\mathrm{m}$ & $170 \mathrm{ng} / \mathrm{L}$ & [24] \\
\hline & Intermediate & $\mathrm{b}$ & $\mathrm{m}$ & $224 \mathrm{ng} / \mathrm{L}$ & [24] \\
\hline & River1 & $\mathrm{b}$ & $\mathrm{m}$ & $18 \mathrm{ng} / \mathrm{L}$ & [24] \\
\hline & River2 & $\mathrm{b}$ & $\mathrm{m}$ & $96 \mathrm{ng} / \mathrm{L}$ & [24] \\
\hline & River3 & $\mathrm{b}$ & $\mathrm{m}$ & $60 \mathrm{ng} / \mathrm{L}$ & [24] \\
\hline \multirow[t]{4}{*}{ Ibuprofen } & Influent & c & $\mathrm{p}$ & $21 \mu \mathrm{g} / \mathrm{L}$ & [272] \\
\hline & Effluent & c & $\mathrm{p}$ & $0.06 \mu \mathrm{g} / \mathrm{L}$ & [272] \\
\hline & Activated sludge & c & $\mathrm{p}$ & $2.2 \mu \mathrm{g} / \mathrm{L}$ & [272] \\
\hline & Wastewater & $\mathrm{e}$ & $\mathrm{s}$ & $4.8 \mathrm{mg} / \mathrm{L}$ instrumental & [276] \\
\hline \multirow[t]{8}{*}{ Diclofenac } & Sediment & j & $q$ & $<$ LOD-309 \pm 15.3 & [32] \\
\hline & Influent & c & $\mathrm{p}$ & $3.2 \mu \mathrm{g} / \mathrm{L}$ & [272] \\
\hline & Effluent & c & $\mathrm{p}$ & $<\mathrm{LOD}$ & [272] \\
\hline & Activated sludge & c & $\mathrm{p}$ & $0.15 \mu \mathrm{g} / \mathrm{L}$ & [272] \\
\hline & Influent & $\mathrm{b}$ & $\mathrm{m}$ & 1993 ng/L & [24] \\
\hline & Effluent & $\mathrm{b}$ & $\mathrm{m}$ & $632 \mathrm{ng} / \mathrm{L}$ & [24] \\
\hline & Intermediate & $\mathrm{b}$ & $\mathrm{m}$ & $1665 \mathrm{ng} / \mathrm{L}$ & [24] \\
\hline & River1 & $\mathrm{b}$ & $\mathrm{m}$ & $186-839 \mathrm{ng} / \mathrm{L}$ & [24] \\
\hline \multirow[t]{3}{*}{ Ketoprofen } & Influent & c & $\mathrm{p}$ & $1.5 \mu \mathrm{g} / \mathrm{L}$ & [272] \\
\hline & Effluent & c & $\mathrm{p}$ & $<\mathrm{LOD}$ & [272] \\
\hline & Activated sludge & c & $\mathrm{p}$ & $0.02 \mu \mathrm{g} / \mathrm{L}$ & [272] \\
\hline \multirow[t]{4}{*}{ DEET } & Influent & $\mathrm{b}$ & $\mathrm{m}$ & $124 \mathrm{ng} / \mathrm{L}$ & [24] \\
\hline & Intermediate & $\mathrm{b}$ & $\mathrm{m}$ & $121 \mathrm{ng} / \mathrm{L}$ & [24] \\
\hline & Effluent & $\mathrm{b}$ & $\mathrm{m}$ & 79 ng/L & [24] \\
\hline & River1 & $\mathrm{b}$ & $\mathrm{m}$ & $22-94 \mathrm{ng} / \mathrm{L}$ & [24] \\
\hline \multirow[t]{3}{*}{ Acetaminophen } & Intermediate & $\mathrm{b}$ & $\mathrm{m}$ & $233 \mathrm{ng} / \mathrm{L}$ & [24] \\
\hline & Effluent & $\mathrm{b}$ & $\mathrm{m}$ & $115 \mathrm{ng} / \mathrm{L}$ & [24] \\
\hline & River1 & $\mathrm{b}$ & $\mathrm{m}$ & 93-278 ng/L & [24] \\
\hline Ampicillin & Sediment & j & $\mathrm{q}$ & $50.8 \pm 2.66-369 \pm 9.0$ & [32] \\
\hline Aspirin & Sediment & $\mathrm{j}$ & $\mathrm{q}$ & $212 \pm 1.6-427 \pm 4.47$ & [32] \\
\hline Nalixidic acid & Sediment & $\mathrm{j}$ & $\mathrm{q}$ & $117 \pm 23.1-455 \pm 12.2$ & [32] \\
\hline \multirow[t]{3}{*}{ Clofibiric acid } & Influent & c & $\mathrm{p}$ & $<$ LOD & [272] \\
\hline & Effluent & c & $\mathrm{p}$ & $<\mathrm{LOD}$ & [272] \\
\hline & Activated sludge & c & $\mathrm{p}$ & $<\mathrm{LOD}$ & [272] \\
\hline \multirow[t]{4}{*}{ Estradiol } & Influent & $\mathrm{b}$ & $\mathrm{m}$ & $1165 \mathrm{ng} / \mathrm{L}$ & [24] \\
\hline & Intermediate & $\mathrm{b}$ & $\mathrm{m}$ & $862 \mathrm{ng} / \mathrm{L}$ & [24] \\
\hline & Effluent & $\mathrm{b}$ & $\mathrm{m}$ & $19.8 \mathrm{ng} / \mathrm{L}$ & [24] \\
\hline & River1 & $\mathrm{b}$ & $\mathrm{m}$ & $211-228 \mathrm{ng} / \mathrm{L}$ & [24] \\
\hline \multirow[t]{3}{*}{ Parecetamol } & Influent & & $\mathrm{p}$ & $77 \mu \mathrm{g} / \mathrm{L}$ & [272] \\
\hline & Effluent & c & $\mathrm{p}$ & $0.18 \mu \mathrm{g} / \mathrm{L}$ & [272] \\
\hline & Activated sludge & c & $\mathrm{p}$ & $0.33 \mu \mathrm{g} / \mathrm{L}$ & [272] \\
\hline
\end{tabular}

a-QuEchERS; b-SPE Oasis HLB; c-SPE; d-online SPE reversed phase; $\mathrm{e}-\mathrm{PLE}$; f-MAE-Hf-L/SME; g-PHWE; h-SPE-CE; i-USAEME; j-ultrasonication; l-UPLC MS-MS; m-LC-MSMS; n-LC-DAD-MS; o-LC-UV-ESI-MS; p-GC-MS; q-LC-ESI-MS-MS; r-L.

\section{Conclusions}

Continuous use of PPCPs by both humans and animals on daily basis has hugely contributed to their persistence in the aquatic environment. Although, there is no guideline for PPCPs, the rate at which they are taken up by humans and animals in the environment is risky. They have been listed as endocrine disrupting chemicals. Wastewater treatment plants in Africa are not designed in such a 
way to remove PPCPs. SPE with the use of Oasis HLB and Oasis MCX have been verified to be the most efficient method of extracting PPCPs from water samples and also a means for aqueous samples clean-up. Methanol and water are considered as choice solvent for their extraction from water using liquid chromatographic technique, while ultrasonic extraction has been routinely used for sediment samples, given its low consumption of solvent unlike Soxhlet extraction. LC-MS with triple quadrupole remains the most widely used analytical method of detection because it does not require cumbersome activity like derivatization for GC-MS and has a great advantage as regards matrix effect. Although, efficient result can also be achieved with GC-MS with suitable derivatization of the compounds in spite of poor volatility of certain compounds.

Author Contributions: Conceptualization and writing of the manuscript as part of PhD research work-C.R.O.; review, editing, and revision of the manuscript-A.O.A., O.O.O. and A.I.O.; PhD research supervision and funding-O.O.O. and A.I.O.

Funding: The research was funded by South African Medical Research Council (grant number (UFH/SAMRC/P790).

Acknowledgments: The authors specially thank the South African Medical Research Council (SAMRC) for funding support.

Conflicts of Interest: The authors declare no conflict of interest.

\section{References}

1. Roberts, P.H.; Thomas, K.V. The occurrence of selected pharmaceuticals in wastewater effluent and surface waters of the lower Tyne catchment. Sci. Total Environ. 2006, 356, 143-153. [CrossRef] [PubMed]

2. Rice, S.L.; Mitra, S. Microwave-assisted solvent extraction of solid matrices and subsequent detection of pharmaceuticals and personal care products (PPCPs) using gas chromatography-Mass spectrometry. Anal. Chim. Acta 2007, 589, 125-132. [CrossRef] [PubMed]

3. Caldwell, D.J. Sources of Pharmaceutical Residues in the Environment and Their Control; Hester, R.E., Harrison, R., Eds.; The Royal Society of Chemistry: London, UK, 2016; ISBN 9781782622345.

4. Dẹbska, J.; Kot-wasik, A.; Namieśnik, J.; Kot-wasik, A.; Namie, J. Fate and Analysis of Pharmaceutical Residues in the Aquatic Environment. Crit. Rev. Anal. Chem. 2004, 34, 51-67. [CrossRef]

5. Hernando, M.D.; Mezcua, M.; Fernández-Alba, A.R.; Barceló, D. Environmental risk assessment of pharmaceutical residues in wastewater effluents, surface waters and sediments. Talanta 2006, 69, 334-342. [CrossRef] [PubMed]

6. Kümmerer, K. Pharmaceuticals in the Environment-A Brief Summary; Springer: Berlin/Heidelberg, Germany, 2008.

7. Ebele, A.J.; Abdallah, M.A.; Harrad, S. Pharmaceuticals and personal care products (PPCPs) in the freshwater aquatic environment. Emerg. Contam. 2017, 3, 1-16. [CrossRef]

8. Baker, D.R.; Kasprzyk-hordern, B. Critical evaluation of methodology commonly used in sample collection, storage and preparation for the analysis of pharmaceuticals and illicit drugs in surface water and wastewater by solid phase extraction and liquid chromatography-Mass spectrometry. J. Chromatogr. A 2011, 1218, 8036-8059. [CrossRef]

9. Pietrogrande, M.C.; Basaglia, G. GC-MS analytical methods for the determination of personal-care products in water matrices. Trends Anal. Chem. 2007, 26, 1086-1094. [CrossRef]

10. Liu, J.; Wong, M. Pharmaceuticals and personal care products (PPCPs): A review on environmental contamination in China. Environ. Int. 2013, 59, 208-224. [CrossRef]

11. Daughton, C.G.; Ternes, T.A. Pharmaceuticals and Personal Care Products in the Environment: Agents of Subtle Change? Environ. Health Perspect. 1999, 107, 907-938. [CrossRef]

12. Yang, X.; Flowers, R.C.; Weinberg, H.S.; Singer, P.C. Occurrence and removal of pharmaceuticals and personal care products (PPCPs) in an advanced wastewater reclamation plant. Water Res. 2011, 45, 5218-5228. [CrossRef]

13. Vlachogianni, T.; Valavanidis, A. Pharmaceuticals and Personal Care Products as Contaminants in the Aquatic Environment. A category of organic wastewater pollutants with special characteristics. Pharmakeftiki 2013, 25, 16-23. 
14. Díaz-Cruz, M.S.; García-Galán, M.J.; Guerra, P.; Jelic, A.; Postigo, C.; Eljarrat, E.; Farré, M.; De Alda, M.J.L.; Petrovic, M.; Barceló, D.; et al. Analysis of selected emerging contaminants in sewage sludge. TrAC Trends Anal. Chem. 2009, 28, 1263-1275. [CrossRef]

15. Dussault, E.B.; Balakrishnan, V.K.; Solomon, K.R.; Sibley, P.K. Matrix effects on mass spectrometric determinations of four pharmaceuticals and personal care products in water, sediments, and biota. Can. J. Chem. 2009, 87, 662-672. [CrossRef]

16. Archer, E.; Wolfaardt, G.M.; Van Wyk, J.H. Pharmaceutical and personal care products (PPCPs) as endocrine disrupting contaminants (EDCs) in South African surface waters. Water Res. 2017, 43, 684-706. [CrossRef]

17. Lawrence, E.; Ozekeke, O.; Isioma, T. Distribution and ecological risk assessment of pesticide residues in surface water, sediment and fish from Ogbesse River, Edo State, Nigeria. J. Environ. Chem. Ecotoxicol. 2015, 7, 20-30.

18. Daughton, C.G.; Brooks, B.W. Active pharmaceutical ingredients and aquatic organisms. In Environmental Contaminants in Biota: Interpreting Tissue Concentrations; Taylor and Francis: Philadelphia, PA, USA, 2011.

19. Loraine, G.A.; Pettigrove, M.E. Seasonal variations in concentrations of pharmaceuticals and personal care products in drinking water and reclaimed wastewater in southern California. Environ. Sci. Technol. 2006, 40, 687-695. [CrossRef] [PubMed]

20. Benotti, M.J.; Trenholm, R.A.; Vanderford, B.J.; Holady, J.C.; Stanford, B.D.; Snyder, S.A. Pharmaceuticals and Endocrine Disrupting Compounds in US. Drinking Water. Environ. Sci. Technol. 2009, 43, 597-603. [CrossRef] [PubMed]

21. Dougherty, J.A.; Swarzenski, P.W.; Dinicola, R.S.; Reinhard, M. Occurrence of Herbicides and Pharmaceutical and Personal Care Products in Surface Water and Groundwater around Liberty Bay, Puget Sound, Washington. J. Environ. Qual. 2010, 39, 1173-1180. [CrossRef]

22. Brausch, J.M.; Rand, G.M. A review of personal care products in the aquatic environment: Environmental concentrations and toxicity. Chemosphere 2011, 82, 1518-1532. [CrossRef]

23. Tran, N.H.; Hu, J.; Ong, S.L. Simultaneous determination of PPCPs, EDCs, and artificial sweeteners in environmental water samples using a single-step SPE coupled with HPLC-MS/MS and isotope dilution. Talanta 2013, 113, 82-92. [CrossRef]

24. Pompei, C.M.E.; Campos, L.C.; da Silva, B.F.; Fogo, J.C.; Vieira, E.M. Occurrence of PPCPs in a Brazilian water reservoir and their removal efficiency by ecological filtration. Chemosphere 2019, 226, 210-219. [CrossRef] [PubMed]

25. Perdigo, A.; Petre, A.; Rosal, R.; Rodrı, A.; Agu, A.; Ferna, A.R. Occurrence of emerging pollutants in urban wastewater and their removal through biological treatment followed by ozonation. Water Res. 2010, 44, 578-588.

26. Nieto, A.; Peschka, M.; Borrull, F.; Pocurull, E.; Knepper, T.P.; Marce, R.M. Phosphodiesterase type V inhibitors: Occurrence and fate in wastewater and sewage sludge. Water Res. 2010, 44, 1607-1615. [CrossRef] [PubMed]

27. Al-Farsi, R.S.; Ahmed, M.; Al-Busaidi, A.; Choudri, B.S. Translocation of pharmaceuticals and personal care products (PPCPs) into plant tissues: A review. Emerg. Contam. 2017, 3, 132-137. [CrossRef]

28. Escher, B.I.; Baumgartner, R.; Koller, M.; Treyer, K.; Lienert, J.; Mcardell, C.S. Environmental toxicology and risk assessment of pharmaceuticals from hospital wastewater. Water Res. 2010, 45, 75-92. [CrossRef]

29. Xie, H.; Hao, H.; Xu, N.; Liang, X.; Gao, D.; Xu, Y.; Gao, Y.; Tao, H.; Wong, M. Pharmaceuticals and personal care products in water, sediments, aquatic organisms, and fish feeds in the Pearl River Delta: Occurrence, distribution, potential sources, and health risk assessment. Sci. Total Environ. 2019, 659, 230-239. [CrossRef]

30. Santos, J.L.; Aparicio, I.; Alonso, E. Occurrence and risk assessment of pharmaceutically active compounds in wastewater treatment plants. A case study: Seville city. (Spain). Environ. Int. 2007, 33, 596-601. [CrossRef]

31. Schriks, M.; Heringa, M.B.; Van Der Kooi, M.M.E.; De Voogt, P.; Wezel, A.P. Van Toxicological relevance of emerging contaminants for drinking water quality. Water Res. 2010, 44, 461-476. [CrossRef]

32. Agunbiade, F.O.; Moodley, B. Occurrence and distribution pattern of acidic pharmaceuticals in surface water, wastewater, and sediment of the Msunduzi River, Kwazulu-Natal, South Africa. Environ. Toxicol. Chem. 2016, 35, 36-46. [CrossRef]

33. Albero, B.; Sánchez-Brunete, C.; García-Valcárcel, A.I.; Pérez, R.A.; Tadeo, J.L. Ultrasound-assisted extraction of emerging contaminants from environmental samples. TrAC Trends Anal. Chem. 2015, 71, 110-118. [CrossRef] 
34. Schlumpf, M.; Cotton, B.; Conscience, M.; Hailer, V.; Steinmann, B.; Lichtensteiger, W. In Vitro and in Vivo Estrogenicity of UV Screens. Environ. Health Perspect. 2001, 109, 239-244. [CrossRef] [PubMed]

35. Boberg, J.; Taxvig, C.; Christiansen, S.; Hass, U. Possible endocrine disrupting effects of parabens and their metabolites. Reprod. Toxicol. 2010, 30, 301-312. [CrossRef] [PubMed]

36. Veldhoen, N.; Skirrow, R.C.; Brown, L.L.Y.; Van Aggelen, G.; Helbing, C.C. Effects of Acute Exposure to the Non-steroidal Anti-inflammatory 2 Drug Ibuprofen on the Developing North American Bullfrog (Rana 3 catesbeiana) Tadpole 1. Environ. Sci. Technol. 2014, 48, 10439-10447. [CrossRef] [PubMed]

37. Garrison, A.W.; Pope, J.D.; Allen, F.R. GC/MS analysis of organic compounds in domestic wastewaters. In Identification and Analysis of Organic Pollutants in Water; Keith, C.H., Ed.; Ann Arbor Science Publishers: Ann Arbor, MI, USA, 1976; pp. 517-556.

38. Kümmerer, K. Chemosphere Antibiotics in the aquatic environment-A review-Part I. Chemosphere 2009, 75, 417-434. [CrossRef] [PubMed]

39. Spongberg, A.L.; Witter, J.D. Pharmaceutical compounds in the wastewater process stream in Northwest Ohio. Sci. Total Environ. 2008, 397, 148-157. [CrossRef] [PubMed]

40. Bartelt-Hunt, S.L.; Snow, D.D.; Damon, T.; Shockley, J.; Hoagland, K. The occurrence of illicit and therapeutic pharmaceuticals in wastewater effluent and surface waters in Nebraska. Environ. Pollut. 2009, 157, 786-791. [CrossRef]

41. Lacey, C.; Mcmahon, G.; Bones, J.; Barron, L.; Morrissey, A.; Tobin, J.M. An LC-MS method for the determination of pharmaceutical compounds in wastewater treatment plant influent and effluent samples. Talanta 2008, 75, 1089-1097. [CrossRef] [PubMed]

42. Soliman, M.A.; Pedersen, J.A.; Park, H.; Castaneda-Jimenez, A.; Stenstrom, M.K.; Suffet, I.H.M. Human Pharmaceuticals, Antioxidants, and Plasticizers in Wastewater Treatment Plant and Water Reclamation Plant Effluents. Water Environ. Res. 2007, 79, 156-167. [CrossRef]

43. Ternes, T.A. Occurrence of drugs in German sewage treatment plants and rivers. Water Res. 1998, 32, 3245-3260. [CrossRef]

44. Joss, A.; Siegrist, H.; Wick, A.; Schlüsener, M.; Ternes, T. Are we about to upgrade wastewater treatment for removing organic micropollutants? Water Res. Technol. 2010, 57, 251-255. [CrossRef]

45. Zhou, J.L.; Zhang, Z.L.; Banks, E.; Grover, D.; Jiang, J.Q. Pharmaceutical residues in wastewater treatment works effluents and their impact on receiving river water. J. Hazard. Mater. 2009, 166, 655-661. [CrossRef] [PubMed]

46. Shraim, A.; Diab, A.; Alsuhaimi, A.; Niazy, E.; Metwally, M.; Amad, M.; Sioud, S.; Dawoud, A. Analysis of some pharmaceuticals in municipal wastewater of Almadinah Almunawarah. Arab. J. Chem. 2017, 10, S719-S729. [CrossRef]

47. Kotchen, M.; Kallaos, J.; Wheeler, K.; Wong, C.; Zahller, M. Pharmaceuticals in wastewater: Behavior, preferences, and willingness to pay for a disposal program. J. Environ. Manag. 2009, 90, 1476-1482. [CrossRef] [PubMed]

48. Kasprzyk-hordern, B.; Dinsdale, R.M.; Guwy, A.J. The removal of pharmaceuticals, personal care products, endocrine disruptors and illicit drugs during wastewater treatment and its impact on the quality of receiving waters. Water Res. 2009, 43, 363-380. [CrossRef] [PubMed]

49. Benotti, M.J.; Brownawell, B.J. stributions of Pharmaceuticals in an Urban Estuary during both Dry-and Wet-Weather Conditions. Environ. Sci. Technol. 2007, 41, 5795-5802. [CrossRef] [PubMed]

50. Crisp, T.M.; Clegg, E.D.; Cooper, R.L.; Anderson, D.G.; Baetcke, K.P.; Hoffmann, J.L.; Morrow, M.S.; Rodier, D.J.; Schaeffer, J.E.; Touart, L.W.; et al. Special Report on Environmental Endocrine Disruption: An Effects Assessment and Analysis; Environmental Protection Agency: Washington, DC, USA, 1997.

51. Kümmerer, K. Pharmaceuticals in the Environment-Scope of the Book and Introduction. In Pharmaceuticals in the Environment; Springer: Berlin/Heidelberg, Germany, 2004; pp. 3-11.

52. Sumpter, J.P.; Williams, R.J.; Scholze, M. Modeling Effects of Mixtures of Endocrine Disrupting Chemicals at the River Catchment Scale. Environ. Sci. Technol. 2006, 40, 478-5489. [CrossRef] [PubMed]

53. Rosi-marshall, E.J.; Snow, D.; Bartelt-hunt, S.L.; Paspalof, A.; Tank, J.L. A review of ecological effects and environmental fate of illicit drugs in aquatic ecosystems. J. Hazard. Mater. 2015, 282, 18-25. [CrossRef] [PubMed] 
54. Crain, D.A.; Eriksen, M.; Iguchi, T.; Jobling, S.; Laufer, H.; Leblanc, G.A.; Guillette, L.J. An ecological assessment of bisphenol-A: Evidence from comparative biology. Reprod. Toxicol. 2007, 24, 225-239. [CrossRef]

55. Drury, B.; Scott, J.; Rosi-marshall, E.J.; Kelly, J.J. Triclosan Exposure Increases Triclosan Resistance and Influences Taxonomic Composition of Benthic Bacterial Communities. Environ. Sci. Technol. 2013, 47, 8923-8930. [CrossRef]

56. Klaper, R.; Welch, L. Emerging Contaminant Threats and the Great Lakes: Existing Science, Estimating Relative Risk and Determining Policie; Alliance for the Great Lakes: Chicago, IL, USA, 2011.

57. Jobling, S.; Burn, R.W.; Thorpe, K.; Williams, R.; Tyler, C. Statistical Modeling Suggests that Antiandrogens in Effluents from Wastewater Treatment Works Contribute to Widespread Sexual Disruption in Fish Living in English Rivers. Environ. Health Perspect. 2009, 117, 97-803. [CrossRef]

58. Liney, K.E.; Hagger, J.A.; Tyler, C.R.; Depledge, M.H.; Galloway, T.S.; Jobling, S. Monograph Health Effects in Fish of Long-Term Exposure to Effluents from Wastewater Treatment Works. Environ. Health Perspect. 2006, 114, 81-90. [CrossRef] [PubMed]

59. Guillette, L.J.; Elizabeth, J.; Guillette, A. Environmental Contaminants and Reproductive Abnormalities in Wildlife: Implications for Public Health. Toxicol. Ind. Health 1996, 12, 537-550. [CrossRef] [PubMed]

60. Colborn, T.; Vom Saal, F.S.; Soto, A.M. Developmental Effects of Endocrine-Disrupting Chemicals in Wildlife and Humans. Environ. Health Perspect. 1993, 101, 378-384. Available online: https://www.jstor.org/stable/ 3431890 (accessed on 8 June 2019). [CrossRef] [PubMed]

61. Richardson, B.J.; Lam, P.K.S.; Martin, M. Emerging chemicals of concern: Pharmaceuticals and personal care products (PPCPs) in Asia, with particular reference to Southern China. Mar. Pollut. Bull. 2005, 50, 913-920. [CrossRef] [PubMed]

62. Mutiyar, P.; Mittal, A. Pharmaceuticals and Personal Care Products (PPCPs) Residues in Water Environment of India: A Neglected but Sensitive Issue Pravin K Mutiyar and Atul K Mittal Department of Civil Engineering Indian Institute of Technology Delhi, Hauz Khas, New Delhi 1. 110016. In Proceedings of the 28th National Convention of Environmental and National Seminar on Hazardous Waste Management and Healthcare in India, March 2013; pp. 9-10.

63. Tixier, C.; Singer, H.; Muller, S. Occurrence and fate of carbamazepine, clofibric acid, diclofenac, ibuprofen, ketoprofen, and naproxen in surface waters. Environ. Sci. Technol. 2003, 37, 1061-1068. [CrossRef]

64. Clara, M.; Strenn, B.; Kreuzinger, N. Carbamazepine as a possible anthropogenic marker in the aquatic environment: Investigations on the behaviour of Carbamazepine in wastewater treatment and during groundwater infiltration. Water Res. 2004, 38, 947-954. [CrossRef]

65. Strauch, G.; Möder, M.; Wennrich, R.; Mohrlok, E.U.; Osenbrück, K.; Gläser, H.; Schiedek, T.; Schladitz, T.; Müller, C.; Schirmer, K.; et al. Urban Impact on Soils and Groundwater (Guest Editors-Ulf Mohrlok and Thomas Schiedek) Indicators for Assessing Anthropogenic Impact on Urban Surface and Groundwater. J. Soil Sci. 2008, 8, 23-33.

66. Wolf, L.; Zwiener, C.; Zemann, M. Tracking artificial sweeteners and pharmaceuticals introduced into urban groundwater by leaking sewer networks. Sci. Total Environ. 2012, 430, 8-19. [CrossRef]

67. Faigle, J.; Feldmann, K. Pharmacokinetic Data of Carbamazepine and Its Major Metabolites in Man; Springer: Berlin/Heidelberg, Germany, 1975; pp. 159-165.

68. Chen, Q.; Fan, L.; Zhang, W.; Cao, C. Talanta Separation and determination of abused drugs clenbuterol and salbutamol from complex extractants in swine feed by capillary zone electrophoresis with simple pretreatment. Talanta 2008, 76, 282-287. [CrossRef]

69. Boxall, A.B.A.; Rudd, M.A.; Brooks, B.W.; Caldwell, D.J.; Choi, K.; Hickmann, S.; Innes, E.; Ostapyk, K.; Staveley, J.P.; Verslycke, T.; et al. Review Pharmaceuticals and Personal Care Products in the Environment: What Are the Big Questions? Environ. Health Perspect. 2012, 120, 1221-1229. [CrossRef]

70. Singer, A.; Jose, D.; Grabic, R.; Khan, A.; Lindberg, R.; Fedorova, G.; Fick, J.; Bowes, M.; Olsen, B.; Soderstrom, H. Intra-and Inter-Pandemic Variations of Antiviral, Antibiotics and Decongestants in Wastewater Treatment Plants and Receiving Rivers. PLoS ONE 2014, 9, e108621.

71. Liu, J.; Lu, G.; Ding, J.; Zhang, Z.; Wang, Y. Science of the Total Environment Tissue distribution, bioconcentration, metabolism, and effects of erythromycin in crucian carp (Carassius auratus). Sci. Total Environ. 2014, 490, 914-920. [CrossRef] [PubMed] 
72. Moffitt, C.M. Oral and injectable applications of erythromycin in salmonid fish culture. Vet. Hum. Toxicol. 1991, 33, 49-53. [PubMed]

73. Kallen, B.; Olausson, P.O.; Danielsson, B. Is erythromycin therapy teratogenic in humans? Reprod. Toxicol. 2005, 20, 209-214. [CrossRef] [PubMed]

74. Gaynor, M.; Mankin, A.S. Macrolide Antibiotics: Binding Site, Mechanism of Action, Resistance. Curr. Top. Med. Chem. 2003, 3, 949-960. [CrossRef] [PubMed]

75. Schafhauser, B.H.; Kristofco, L.A.; De Oliveira, C.M.R.; Brooks, B.W. Global review and analysis of erythromycin in the environment: Occurrence, bioaccumulation and antibiotic resistance hazards. Environ. Pollut. 2018, 238, 440-451. [CrossRef] [PubMed]

76. Liao, C.; Chen, L.; Kannan, K. Occurrence of parabens in foodstuffs from China and its implications for human dietary exposure. Environ. Int. 2013, 57, 68-74. [CrossRef]

77. Andersen, F. Final Amended Report on the Safety Assessment of Methylparaben, Ethylparaben, Propylparaben, and Benzylparaben as used in Cosmetic Products 1. Int. J. Toxicol. 2008, 27, 1-82.

78. Soni, M.G. Safety assessment of esters of p-hydroxybenzoic acid (parabens). Food Chem. Toxicol. 2005, 43, 985-1015. [CrossRef]

79. Bledzka, D.; Gromadziifiska, J.; Wasowics, W. Parabens. From environmental studies to human health. Environ. Int. 2014, 67, 27-42. [CrossRef]

80. Darbre, P.D.; Aljarrah, A.; Miller, W.R.; Coldham, N.G.; Sauer, M.J.; Pope, G.S. Concentrations of Parabens in Human Breast Tumours. J. Appl. Toxicol. Int. J. 2004, 13, 5-13. [CrossRef] [PubMed]

81. Parameters, S.Q.; Damage, S.D.N.A.; Meeker, J.D.; Yang, T.; Ye, X.; Calafat, A.M.; Hauser, R. Urinary Concentrations of Parabens and Serum Hormone Levels. Environ. Health Persperct. 2011, 119, 252-257.

82. Liao, C.; Kannan, K. Science of the Total Environment Concentrations and composition profiles of parabens in currency bills and paper products including sanitary wipes. Sci. Total Environ. 2014, 475, 8-15. [CrossRef] [PubMed]

83. Albero, B.; Pérez, R.A.; Sánchez-Brunete, C.; Tadeo, J.L. Occurrence and analysis of parabens in municipal sewage sludge from wastewater treatment plants in Madrid (Spain). J. Hazard. Mater. 2012, 239-240, 48-55. [CrossRef] [PubMed]

84. Li, W.; Shi, Y.; Gao, L.; Liu, J.; Cai, Y. Occurrence, fate and risk assessment of parabens and their chlorinated derivatives in an advanced wastewater treatment plant. J. Hazard. Mater. 2015, 300, 29-38. [CrossRef]

85. Feng, Y.; Gao, C.; Tong, X.; Chen, S.; Lei, Z.; Wang, J. Spatial Patterns of Land Surface Temperature and Their Influencing Factors: A Case Study in Suzhou, China. Remote Sens. 2019, 11, 182. [CrossRef]

86. Guo, Y.; Wang, L.; Kannan, K. Phthalates and Parabens in Personal Care Products from China: Concentrations and Human Exposure. Arch. Environ. Contam. Toxicol. 2014, 66, 113-119. [CrossRef]

87. Kitchen, L.W.; Lawrence, K.L.; Coleman, R.E. The role of the United States military in the development of vector control products, including insect repellents, insecticides, and bed nets. J. Vector Ecol. 2009, 34, 50-61. [CrossRef]

88. Schoenig, G.P.; Osimitz, T.G.; Gabriel, K.L.; Hartnagel, R.; Gill, M.W.; Goldenthal, E.I. Evaluation of the Chronic Toxicity and Oncogenicity of N, N-Diethyl-m-Toluamide (DEET). Toxicol. Sci. Off. J. Soc. Toxicol. 1999, 47, 99-109. [CrossRef]

89. Pennetier, C.; Chabi, J.; Martin, T.; Chandre, F.; Rogier, C.; Hougard, J. New protective battle-dress impregnated against mosquito vector bites. Parasites Vectors 2010, 3, 81. [CrossRef]

90. Lee, L.K.; He, J. Reductive Debromination of Polybrominated Diphenyl Ethers by Anaerobic Bacteria from Soils and Sediments. Appl. Environ. Microbiol. 2010, 76, 794-802. [CrossRef] [PubMed]

91. Merel, S.; Snyder, S.A. Critical assessment of the ubiquitous occurrence and fate of the insect repellent $\mathrm{N}$, N-diethyl-m-toluamide in water. Environ. Int. 2016, 96, 98-117. [CrossRef] [PubMed]

92. Bedoux, G.; Roig, B.; Thomas, O.; Dupont, V.; Bot, B. Le Occurrence and toxicity of antimicrobial triclosan and by-products in the environment. Environ. Sci. Pollut. Res. 2012, 19, 1044-1065. [CrossRef] [PubMed]

93. Fair, P.A.; Lee, H.; Adams, J.; Darling, C.; Pacepavicius, G.; Alaee, M.; Bossart, G.D.; Henry, N.; Muir, D. Occurrence of triclosan in plasma of wild Atlantic bottlenose dolphins (Tursiops truncatus) and in their environment. Environ. Pollut. 2009, 157, 2248-2254. [CrossRef]

94. Zhao, J.; Ying, G.; Liu, Y.; Chen, F.; Yang, J.; Wang, L. Occurrence and risks of triclosan and triclocarban in the Pearl River system, South China: From source to the receiving environment. J. Hazard. Mater. 2010, 179, 215-222. [CrossRef] [PubMed] 
95. Fredholm, B.B.; Bättig, K.; Holmén, J.; Nehlig, A.; Zvartau, E.E. Actions of Caffeine in the Brain with Special Reference to Factors That Contribute to Its Widespread Use. Pharmacol. Rev. 1999, 51, 83-133. [PubMed]

96. Lee, Y.; Jun, S.; Montell, C. Multiple gustatory receptors required for the caffeine response in Drosophila. Natl. Acad. Sci. 2009, 106, 4495-4500. [CrossRef] [PubMed]

97. Wright, G.A.; Baker, D.D.; Palmer, M.J.; Stabler, D.; Mustard, J.A.; Power, E.F. Europe PMC Funders Group Caffeine in floral nectar enhances a pollinator's memory of reward. Science 2015, 339, 1202-1204. [CrossRef] [PubMed]

98. Doepker, C.; Lieberman, H.R.; Smith, A.P.; Peck, J.D.; El-sohemy, A.; Welsh, B.T. Caffeine: Friend or Foe? Annu. Rev. Food Sci. Technol. 2016, 7, 117-137. [CrossRef] [PubMed]

99. Bu, Q.; Wang, B.; Huang, J.; Deng, S.; Yu, G. Pharmaceuticals and personal care products in the aquatic environment in China: A review. J. Hazard. Mater. 2013, 262, 189-211. [CrossRef]

100. Snyder, S.A. Ozone: Science and Engineering Occurrence, Treatment, and Toxicological Relevance of EDCs and Pharmaceuticals in Water Occurrence, Treatment, and Toxicological Relevance of EDCs and Pharmaceuticals in Water. Ozone Sci. Eng. 2008, 30, 65-69. [CrossRef]

101. Houtman, C.J.; Brouwer, A.; Lamoree, M.H. Identification of Estrogenic Compounds in Fish Bile Using Bioassay-Directed Fractionation. Environ. Sci. Technol. 2004, 38, 6415-6423. [CrossRef] [PubMed]

102. Verlicchi, P.; Al Aukidy, M.; Zambello, E. Science of the Total Environment Occurrence of pharmaceutical compounds in urban wastewater: Removal, mass load and environmental risk after a secondary treatment -A review. Sci. Total Environ. 2012, 429, 123-155. [CrossRef] [PubMed]

103. Vieno, N.; Tuhkanen, T.; Kronberg, L. Seasonal Variation in the Occurrence of Pharmaceuticals in Effluents from a Sewage Treatment Plant and in the Recipient Water. Environ. Sci. Technol. 2005, 39, 8220-8226. [CrossRef] [PubMed]

104. Lam, M.W.; Mabury, S.A. Photodegradation of the pharmaceuticals atorvastatin, carbamazepine, levofloxacin, and sulfamethoxazole in natural waters. Aquat. Sci. 2005, 67, 177-188.

105. Science, E.; Walters, D.M.; States, U.; Survey, G.; Jardine, T.; Kidd, K.A. Trophic Magnification of Organic Chemicals: A Global Synthesis. Environ. Sci. Technol. 2016, 50, 4650-4658.

106. Richmond, E.K.; Grace, M.R.; Kelly, J.J.; Reisinger, A.J.; Rosi, E.J.; Walters, D.M. Pharmaceuticals and personal care products (PPCPs) are ecological disrupting compounds (EcoDC). Elem. Sci. Anth. 2017, 5, 66. [CrossRef]

107. Brooks, B.W.; Riley, T.M.; Taylor, R.D. Water quality of effluent-dominated ecosystems: Ecotoxicological, hydrological, and management considerations. Hydrobiologia 2006, 556, 365-379. [CrossRef]

108. Brown, J.N.; Pax, N.; Lars, F.; Larsson, D.G.J. Variations in bioconcentration of human pharmaceuticals from sewage effluents into fish blood plasma. Environ. Toxicol. Pharmacol. 2007, 24, 267-274. [CrossRef]

109. Hughes, S.R.; Kay, P.; Brown, L.E. Global Synthesis and Critical Evaluation of Pharmaceutical Data Sets Collected from River Systems. Environ. Sci. Technol. 2013, 47, 661-677. [CrossRef]

110. Muir, D.; Simmons, D.; Wang, X.; Peart, T.; Villella, M.; Miller, J.; Sherry, J. Bioaccumulation of pharmaceuticals and personal care product chemicals in fish exposed to wastewater effluent in an urban wetland. Sci. Rep. 2017, 7, 16999. [CrossRef] [PubMed]

111. Sin, E.; Tan, S.; Ho, B.Y.; Zakaria, M.P.; Latif, P.A.; Saari, N. Simultaneous extraction and determination of pharmaceuticals and personal care products (PPCPs) in river water and sewage by solid-phase extraction and liquid chromatography-tandem mass spectrometry. Int. J. Environ. Anal. Chem. 2015, 95, 816-832.

112. Wang, Y.; Wang, X.; Li, M.; Dong, J.; Sun, C.; Chen, G. Removal of Pharmaceutical and Personal Care Products (PPCPs) from Municipal Waste Water with Integrated Membrane Systems, MBR-RO/NF. Anal. Lett. 2015, 48, 944-954. [CrossRef]

113. Fent, K.; Weston, A. Ecotoxicology of human pharmaceuticals. Aquat. Toxicol. 2006, 76, 122-159. [CrossRef] [PubMed]

114. Jjemba, P.K. Excretion and ecotoxicity of pharmaceutical and personal care products in the environment. Ecotoxicol. Environ. Saf. 2006, 63, 113-130. [CrossRef] [PubMed]

115. Kim, I.; Tanaka, H. Photodegradation characteristics of PPCPs in water with UV treatment. Environ. Int. 2009, 35, 793-802. [CrossRef]

116. Parrott, J.L.; Blunt, B.R. Life-Cycle Exposure of Fathead Minnows (Pimephales promelas) to an Ethinylestradiol Concentration Below $1 \mathrm{ng} / \mathrm{L}$ Reduces Egg Fertilization Success and Demasculinizes Males. Environ. Toxicol. Int. J. 2005, 20, 131-141. [CrossRef] 
117. Reinhard, L.; Hutchinson, T.H.; Croudace, C.P.; Siegmund, F.; Schweinfurth, H.; Hampe, P.; Panter, G.H.; Sumpter, J.P. Effects of the synthetic estrogen $17 \alpha$-ethinylestradiol on the life-cycle of the fathead minnow (Pimephales promelas). Environ. Toxicol. Chem. Int. J. 2001, 20, 1216-1227.

118. Dussault, E.; Balakrishnan, V.; Sverko, E.; Solomon, K.; Sible, P. Toxicity of human pharmaceuticals and personal care products to Benthic invertebrates. Environ. Toxicol. Chem. 2008, 27, 425-432. [CrossRef]

119. Delorenzo, M.E.; Fleming, J. Individual and Mixture Effects of Selected Pharmaceuticals and Personal Care Products on the Marine Phytoplankton Species Dunaliella tertiolecta. Arch. Environ. Contam. Toxicol. 2008, 54, 203-210. [CrossRef]

120. Berendonk, T.U.; Manaia, C.M.; Merlin, C.; Fatta-Kassinos, D.; Cytryn, E.; Walsh, F.; Bürgmann, H.; Sørum, H.; Norström, M.; Pons, M.N.; et al. Tackling antibiotic resistance: The environmental framework. Nat. Rev. Microbiol. 2015, 13, 310. [CrossRef] [PubMed]

121. Becker, J.; Stefanakis, A. Pharmaceuticals and Personal Care Products as Emerging Water Contaminants; IGI Global: Hershey, PA, USA, 2017; pp. 81-100.

122. Caliman, F.A.; Gavrilescu, M. Review Pharmaceuticals, Personal Care Products and Endocrine Disrupting Agents in the Environment-A Review. CLEAN Soil Air Water 2009, 37, 277-303. [CrossRef]

123. Van Wieren, E.M.; Seymour, M.D.; Peterson, J.W. Science of the Total Environment Interaction of the fluoroquinolone antibiotic, ofloxacin, with titanium oxide nanoparticles in water: Adsorption and breakdown. Sci. Total Environ. 2012, 441, 1-9. [CrossRef] [PubMed]

124. Heberer, T. Occurrence, fate, and removal of pharmaceutical residues in the aquatic environment: A review of recent research data. Toxicol. Lett. 2002, 131, 5-17. [CrossRef]

125. Pedersen, J.A.; Soliman, M.; Suffet, I.H. Human pharmaceuticals, hormones, and personal care product ingredients in runoff from agricultural fields irrigated with treated wastewater. J. Agricult. Food Chem. 2005, 53, 1625-1632. [CrossRef]

126. Kleywegt, S.; Smyth, S.; Parrott, K.; Schaefer, E.; Lagace, M.; Payne, E.; Topp, A.; Beck, A.; McLaughlin, K.; Ostapyk, K. Pharmaceuticals and Personal Care Products in the Canadian Environment: Research and Policy Directions, NWRI, 2007. Sci. Assess. Rep. Ser. 2007, 8, 53.

127. Wu, X.; Conkle, J.L.; Ernst, F.; Gan, J. Treated Wastewater Irrigation: Uptake of Pharmaceutical and Personal Care Products by Common Vegetables under Field Conditions. Environ. Sci. Technol. 2014, 48, 11286-11293. [CrossRef] [PubMed]

128. Wu, X.; Dodgen, L.K.; Conkle, J.L.; Gan, J. Science of the Total Environment Plant uptake of pharmaceutical and personal care products from recycled water and biosolids: A review. Sci. Total Environ. 2015, 536, 655-666. [CrossRef]

129. Boxall, A.B.A. The environmental side effects of medication. EMBO Rep. 2004, 5, 1110-1116. [CrossRef]

130. Xiang, N.; Zhao, X.; Meng, X.; Chen, L. Science of the Total Environment Polybrominated diphenyl ethers (PBDEs) in a conventional wastewater treatment plant (WWTP) from Shanghai, the Yangtze River Delta: Implication for input source and mass loading. Sci. Total Environ. 2013, 461, 391-396. [CrossRef]

131. Wu, C.; Spongberg, A.L.; Witter, J.D.; Fang, M.; Ames, A.; Czajkowski, K.P. Detection of Pharmaceuticals and Personal Care Products in Agricultural Soils Receiving Biosolids Application. CLEAN Soil Air Water 2010, 38, 230-237. [CrossRef]

132. Conkle, J.L.; Gan, J.; Anderson, M.A. Degradation and sorption of commonly detected PPCPs in wetland sediments under aerobic and anaerobic conditions. J. Soils Sediments 2012, 12, 1164-1173. [CrossRef]

133. Gilroy, È.A.M.; Balakrishnan, V.K.; Solomon, K.R.; Sverko, E.; Sibley, P.K. Chemosphere Behaviour of pharmaceuticals in spiked lake sediments-Effects and interactions with benthic invertebrates. Chemosphere 2012, 86, 578-584. [CrossRef] [PubMed]

134. Fatta, D.; Nikolaou, A.; Achilleos, A.; Meriç, S. Analytical methods for tracing pharmaceutical residues in water and wastewater. Trends Anal. Chem. 2007, 26, 515-533. [CrossRef]

135. Gonçalves, C.M.O.; Sousa, M.A.D.; Alpendurada, M.D.F.P. Analysis of acidic, basic and neutral pharmaceuticals in river waters: Clean-up by $1^{\circ}, 2^{\circ}$ amino anion exchange and enrichment using a hydrophilic adsorbent. Int. J. Environ. Anal. Chem. 2013, 93, 1-22. [CrossRef]

136. Gracia-lor, E.; Sancho, J.V.; Serrano, R.; Hernández, F. Chemosphere Occurrence and removal of pharmaceuticals in wastewater treatment plants at the Spanish Mediterranean area of Valencia. Chemosphere 2012, 87, 453-462. [CrossRef] [PubMed] 
137. Knee, K.L.; Gossett, R.; Boehm, A.B.; Paytan, A. Caffeine and agricultural pesticide concentrations in surface water and groundwater on the north shore of Kauai (Hawaii, USA). Mar. Pollut. Bull. 2010, 60, 1376-1382. [CrossRef] [PubMed]

138. Nikolaou, A.; Meric, S.; Fatta, D. Occurrence patterns of pharmaceuticals in water and wastewater environments. Anal. Bioanal. Chem. 2007, 387, 1225-1234. [CrossRef] [PubMed]

139. Cunningham, V.; Buzby, M.; Hutchinson, T.; Masstrocco, F.; Parke, N.; Roden, N. Effects of HUMAN on Aquatic Life: next steps. Environ. Sci. Technol. 2006, 3457-3462.

140. Sui, Q.; Cao, X.; Lu, S.; Zhao, W.; Qiu, Z.; Yu, G. Occurrence, sources and fate of pharmaceuticals and personal care products in the groundwater: A review. Emerg. Contam. 2015, 1, 14-24. [CrossRef]

141. Suppes, L.M.; Huang, C.; Lee, W.; Brockman, K.J. Sources of pharmaceuticals and personal care products in swimming pools. J. Water Health 2017, 15, 829-834. [CrossRef] [PubMed]

142. Hao, C.; Zhao, X.; Yang, P. GC-MS and HPLC-MS analysis of bioactive pharmaceuticals and personal-care products in environmental matrices. TrAC Trends Anal. Chem. 2007, 26, 569-580. [CrossRef]

143. Caldwell, D. Pharmaceuticals in the environment. In Issues in Environmental Science and Technology; Hester, R., Harrison, R.M., Eds.; Royal Society of Chemistry: London, UK, 2015.

144. Larsson, D.G.J.; De Pedro, C.; Paxeus, N. Effluent from drug manufactures contains extremely high levels of pharmaceuticals. J. Hazard. Mater. 2007, 148, 751-755. [CrossRef] [PubMed]

145. Chen, L.; Song, D.; Tian, Y.; Ding, L.; Yu, A.; Zhang, H. Application of on-line microwave sample-preparation techniques. Trends Anal. Chem. 2008, 27, 151-159. [CrossRef]

146. Sanchez-prado, L.; Garcia-jares, C.; Llompart, M. Microwave-assisted extraction: Application to the determination of emerging pollutants in solid samples. J. Chromatogr. A 2010, 1217, 2390-2414. [CrossRef] [PubMed]

147. Vanderford, B.J.; Mawhinney, D.B.; Snyder, S.A. Assessment of sample preservation techniques for pharmaceuticals, personal care products, and steroids in surface and drinking water. Anal. Bioanal. Chem. 2011, 399, 2227-2234. [CrossRef]

148. Englert, B. Method 1694: Pharmaceuticals and Personal Care Products in Water, Soil, Sediment, and Biosolids by HPLC/MS/MS; EPA: Washington, DC, USA, 2007; pp. 1-72.

149. EPA. Method 1614A: Brominated Diphenyl Ethers in Water, Soil, Sediment, and Tissue by HRGC/HRMS; EPA: Washington, DC, USA, 2010.

150. Ortiz, S.; García, D.; García-encina, P.A.; Irusta-mata, R. Science of the Total Environment The potential ecotoxicological impact of pharmaceutical and personal care products on humans and freshwater, based on USEtox $^{\mathrm{TM}}$ characterization factors. A Spanish case study of toxicity impact scores. Sci. Total Environ. 2017, 609, 429-445. [CrossRef]

151. Jones-Lepp, T.L.; Stevens, R. Pharmaceuticals and personal care products in biosolids/sewage sludge: The interface between analytical chemistry and regulation. Am. Water Work. Assoc. 2007, 387, 1173-1183.

152. Kasprzyk-Hordern, B.; Dinsdale, R.M.; Guwy, A.J. The occurrence of pharmaceuticals, personal care products, endocrine disruptors and illicit drugs in surface water in South Wales, UK. Water Res. 2008, 42, 3498-3518. [CrossRef]

153. Glassmeyer, S.; Furlong, E.; Kolpin, D.; Cahill, J.; Zaugg, S. Transport of Chemical and Microbial Compounds from Known Wastewater Discharges: Potential for Use as Indicators of Human Fecal Contamination. Environ. Sci. Technol. 2005, 39, 5157-5169. [CrossRef]

154. Ashton, D.; Hilton, M.; Thomas, K.V. Investigating the environmental transport of human pharmaceuticals to streams in the United Kingdom. Sci. Total Environ. 2004, 333, 167-184. [CrossRef]

155. Bendz, D.; Pax, N.A.; Ginn, T.R.; Loge, F.J. Occurrence and fate of pharmaceutically active compounds in the environment, a case study: Hoje River in Sweden. J. Hazard. Mater. 2005, 122, 195-204. [CrossRef] [PubMed]

156. Kolpin, D.; Furlong, E.; Zaugg, S. Pharmaceuticals, Hormones, and Other Organic Wastewater Contaminants in US Streams, 1999-2000: A National Reconnaissance. Environ. Sci. Technol. 2002, 36, 1999-2000.

157. Hummel, D.; Loffler, D.; Fink, G.; Ternes, T. Simultaneous determination of psychoactive drugs and their metain fish: Results of a national pilot study in the United States. Environ. Toxicol. Chem. 2006, 28, 2587-2597.

158. Kolpin, D.W.; Skopec, M.; Meyer, M.T.; Furlong, E.T.; Zaugg, S.D. Urban contribution of pharmaceuticals and other organic wastewater contaminants to streams during differing flow conditions. Sci. Total Environ. 2004, 328, 119-130. [CrossRef] 
159. Moldovan, Z. Occurrences of pharmaceutical and personal care products as micropollutants in rivers from Romania. Chemosphere 2006, 64, 1808-1817. [CrossRef]

160. Vanderford, B.J.; Pearson, R.A.; Rexing, D.J.; Snyder, S.A. Analysis of Endocrine Disruptors, Pharmaceuticals, and Personal Care Products in Water Using Liquid Chromatography/Tandem Mass Spectrometry. Anal. Chem. 2003, 75, 6265-6274. [CrossRef]

161. Zuccato, E.; Castiglioni, S.; Fanelli, R.; Reitano, G.; Bagnati, R.; Chiabrando, C.; Pomati, F.; Rossetti, C.; Calamari, D. Pharmaceuticals in the Environment in Italy: Causes, Occurrence, Effects and Control. Environ. Sci. Pollut. Res. 2006, 13, 15-21. [CrossRef]

162. Calamari, D.; Zuccato, E.; Castiglioni, S.; Bagnati, R.; Fanelli, R. Strategic Survey of Therapeutic Drugs in the Rivers Po and Lambro in Northern Italy. Environ. Sci. Technol. 2003, 37, 1241-1248. [CrossRef]

163. Gros, M.; Petrovi, M. Development of a multi-residue analytical methodology based on liquid chromatography-Tandem mass spectrometry (LC-MS/MS) for screening and trace level determination of pharmaceuticals in surface and wastewaters. Talanta 2006, 70, 678-690. [CrossRef]

164. Lin, K.; Gan, J. Chemosphere Sorption and degradation of wastewater-associated non-steroidal anti-inflammatory drugs and antibiotics in soils. Chemosphere 2011, 83, 240-246. [CrossRef] [PubMed]

165. Zhao, J.; Zhang, Q.; Chen, F.; Wang, L.; Ying, G.; Liu, Y.; Yang, B.; Zhou, L.; Liu, S.; Su, H.; et al. Evaluation of triclosan and triclocarban at river basin scale using monitoring and modeling tools: Implications for controlling of urban domestic sewage discharge. Water Res. 2012, 47, 395-405. [CrossRef] [PubMed]

166. Jiao, S.; Zheng, S.; Yin, D.; Wang, L.; Chen, L. Chemosphere Aqueous photolysis of tetracycline and toxicity of photolytic products to luminescent bacteria. Chemosphere 2008, 73, 377-382. [CrossRef] [PubMed]

167. Liu, S.; Ying, G.; Zhao, J.; Chen, F.; Yang, B.; Zhou, L.; Lai, H. Trace analysis of 28 steroids in surface water, wastewater and sludge samples by rapid resolution liquid chromatography_Electrospray ionization tandem mass spectrometry. J. Chromatogr. A 2011, 1218, 1367-1378. [CrossRef] [PubMed]

168. Hu, X.; Zhou, Q.; Luo, Y. Occurrence and source analysis of typical veterinary antibiotics in manure, soil, vegetables and groundwater from organic vegetable bases, northern China. Environ. Pollut. 2010, 158, 2992-2998. [CrossRef] [PubMed]

169. Xu, J.; Chen, W.; Wu, L.; Green, R.; Chang, A.C. Leachability of some emerging contaminants in reclaimed municipal wastewater-irrigated turf grass fields. Environ. Toxicol. Chem. Int. J. 2009, 28, 1842-1850. [CrossRef] [PubMed]

170. Xu, J.; Wu, L.; Chen, W.; Chang, A.C. Leaching potential of nonsteroidal anti-inflammatory drugs in soils. Environ. Toxicol. Chem. Int. J. 2010, 29, 800-807. [CrossRef] [PubMed]

171. Qiao, T.; Yu, Z.; Au, D.W.T. Occurrence and fate of pharmaceuticals and personal care products in drinking water in southern China. J. Environ. Monit. 2011, 13, 3097-3103. [CrossRef] [PubMed]

172. Gibson, R.; Smith, M.D.; Spary, C.J. Mixtures of Estrogenic Contaminants in Bile of Fish Exposed to Wastewater Treatment Works Effluents. Environ. Sci. Technol. 2005, 39, 2461-2471. [CrossRef]

173. Ramirez, A.J.; Mottaleb, M.A.; Brooks, B.W.; Chambliss, C.K. Analysis of pharmaceuticals in fish using liquid chromatography-tandem mass spectrometry. Anal. Chem. 2007, 79, 3155-3163. [CrossRef] [PubMed]

174. Oaks, J.L.; Gilbert, M.; Virani, M.Z.; Watson, R.T.; Meteyer, C.U.; Rideout, B.A.; Shivaprasad, H.L.; Ahmed, S.; Chaudhry, M.J.I.; Arshad, M.; et al. Diclofenac residues as the cause of vulture population decline in Pakistan. Nature 2004, 427, 630. [CrossRef] [PubMed]

175. Li, W.; Shi, Y.; Gao, L.; Liu, J.; Cai, Y. Chemosphere Occurrence of antibiotics in water, sediments, aquatic plants, and animals from Baiyangdian Lake in North China. Chemosphere 2012, 89, 1307-1315. [CrossRef] [PubMed]

176. Chen, J.; Zhou, X.; Nie, X.; Jiang, T. Fate of Ciprofloxacin in a simulated micro-cosmos system by different exposure ways. Acta Ecol. Sin. 2007, 27, 5300-5307.

177. Liu, J.; Wang, R.; Huang, B.; Lin, C.; Wang, Y.; Pan, X. Distribution and bioaccumulation of steroidal and phenolic endocrine disrupting chemicals in wild fish species from Dianchi Lake, China. Environ. Pollut. 2011, 159, 2815-2822. [CrossRef] [PubMed]

178. Ali, A.M.; Thorsen, H.; Sydnes, L.K.; Alarif, W.M.; Kallenborn, R.; Al-lihaibi, S.S. Science of the Total Environment Detection of PPCPs in marine organisms from contaminated coastal waters of the Saudi Red Sea. Sci. Total Environ. 2018, 621, 654-662. [CrossRef] [PubMed] 
179. Gatermann, R.; Biselli, S.; Hühnerfuss, H.; Rimkus, G.G.; Hecker, M.; Karbe, L. Synthetic musks in the environment. Part 1: Species-dependent bioaccumulation of polycyclic and nitro musk fragrances in freshwater fish and mussels. Arch. Environ. Contam. Toxicol. 2002, 42, 437-446. [CrossRef] [PubMed]

180. Brooks, B.W.; Chambliss, C.K.; Stanley, J.K.; Ramirez, A.; Banks, K.E.; Johnson, R.D.; Lewis, R.J. Determination of select antidepressants in fish from an effluent-dominated stream. Environ. Toxicol. Chem. Int. J. 2005, 24, 464-469. [CrossRef]

181. Nakata, H. Occurrence of synthetic musk fragrances in marine mammals and sharks from Japanese coastal waters. Environ. Sci. Technol. 2005, 39, 3430-3434. [CrossRef] [PubMed]

182. Ramirez, A.J.; Brain, R.A.; Usenko, S.; Mottaleb, M.A.; O’Donnell, J.G.; Stahl, L.L.; Wathen, J.B.; Snyder, B.D.; Pitt, J.L.; Perez-Hurtado, P.; et al. Occurrence of pharmaceuticals and personal care products in fish: Results of a national pilot study in the United States. Environ. Toxicol. Chem. 2009, 28, 2587-2597. [CrossRef] [PubMed]

183. Mottaleb, M.A.; Usenko, S.; Donnell, J.G.O.; Ramirez, A.J.; Brooks, B.W.; Chambliss, C.K. Gas chromatography-Mass spectrometry screening methods for select UV filters, synthetic musks, alkylphenols, an antimicrobial agent, and an insect repellent in fish. J. Chromatogr. A 2009, 1216, 815-823. [CrossRef] [PubMed]

184. Kwon, J. Determination of 17-Ethynylestradiol, Carbamazepine, Diazepam, Simvastatin, and Oxybenzone in Fish Livers. J. Chromatogr. A 2009, 92, 359-371.

185. Boehmer, W.; Ruedel, H.; Wenzel, A.; Schroeter-Kermani, C. Retrospective Monitoring of Triclosan and Methyl-triclosan in Fish: Results from the German Environmental Specimen. Organohalogen. Compd. 2004, $66,1516-1521$.

186. Wenzel, A.; Bo, W. Retrospective Monitoring of Alkylphenols and Alkylphenol Monoethoxylates in Aquatic Biota from 1985 to 2001: Results from the German Environmental Specimen. Environ. Sci. Technol. 2004, 38, 1654-1661. [CrossRef] [PubMed]

187. Sanchez-Prado, L.; Garcia-Jares, C.; Dagnac, T.; Llompart, M. Trends in Analytical Chemistry Microwave-assisted extraction of emerging pollutants in environmental and biological samples before chromatographic determination. Trends Anal. Chem. 2015, 71, 119-143. [CrossRef]

188. Nieto, A.; Borrull, F.; Pocurull, E.; Marce, R.M. Pressurized liquid extraction: A useful technique to extract pharmaceuticals and personal-care products from sewage sludge. TrAC Trends Anal. Chem. 2010, 29, 752-764. [CrossRef]

189. Pérez-Lemus, N.; López-Serna, R.; Pérez-Elvira, S.I.; Barrado, E. Analytical methodologies for the determination of pharmaceuticals and personal care products (PPCPs) in sewage sludge: A critical review. Anal. Chim. Acta 2019. [CrossRef]

190. Diaz-Cruz, S.; De Alda, J.L.; Barcelo, D. Determination of antimicrobials in sludge from infiltration basins at two artificial recharge plants by pressurized liquid extraction-Liquid chromatography-Tandem mass spectrometry. J. Chromatogr. A 2006, 1130, 72-82. [CrossRef]

191. Gatidou, G.; Thomaidis, N.S.; Stasinakis, A.S.; Lekkas, T.D. Simultaneous determination of the endocrine disrupting compounds nonylphenol, nonylphenol ethoxylates, triclosan and bisphenol A in wastewater and sewage sludge by gas chromatography-Mass spectrometry. J. Chromatogr. A 2007, 1138, 32-41. [CrossRef]

192. Ternes, T.A.; Andersen, H.; Gilberg, D.; Bonerz, M.; Flo, D. Determination of Estrogens in Sludge and Sediments by Liquid Extraction and GC/MS/MS. Anal. Chem. 2002, 74, 3498-3504. [CrossRef]

193. Nieto, A.; Borrull, F.; Pocurull, E.; Marcé, R.M. Determination of natural and synthetic estrogens and their conjugates in sewage sludge by pressurized liquid extraction and liquid chromatography-Tandem mass spectrometry. J. Chromatogr. A 2008, 1213, 224-230. [CrossRef]

194. Miege, C.; Dugay, J.; Hennion, M.C. Optimization, validation and comparison of various extraction techniques for the trace determination of polycyclic aromatic hydrocarbons in sewage sludges by liquid chromatography coupled to diode-array and fluorescence detection. J. Chromatogr. A 2003, 995, 87-97. [CrossRef]

195. Morales, S.; Canosa, P.; Rodr, I.; Cela, R. Microwave assisted extraction followed by gas chromatography with tandem mass spectrometry for the determination of triclosan and two related chlorophenols in sludge and sediments. Anal. Chim. Acta. 2005, 1082, 128-135. [CrossRef] [PubMed]

196. Shin, M.; Svoboda, M.L.; Falletta, P. Microwave-assisted extraction (MAE) for the determination of polybrominated diphenylethers (PBDEs) in sewage sludge. Anal. Bioanal. Chem. 2007, 387, 2923-2929. [CrossRef] [PubMed] 
197. Gobel, A.; Thomsen, A.; Mcardell, C.; Alder, A.C.; Giger, W.; Theiß, N.; Loffler, D.; Ternes, T.A. Extraction and determination of sulfonamides, macrolides, and trimethoprim in sewage sludge. J. Chromatogr. A 2005, 1085, 179-189. [CrossRef] [PubMed]

198. Golet, E.; Alder, A.; Giger, W. Environmental exposure and risk assessment of fluoroquinolone antibacterial agents in wastewater and river water of the Glatt Valley Watershed, Switzerland. Environ. Sci. Technol. 2002, 36, 3645-3651. [CrossRef] [PubMed]

199. Tobiszewski, M.; Mechlinska, A.; Zygmunt, B.; Namiesnik, J. Green analytical chemistry in sample preparation for determination of trace organic pollutants. Trends Anal. Chem. 2009, 28, 943-951. [CrossRef]

200. Guitart, C.; Readman, J.W. Analytica Chimica Acta Critical evaluation of the determination of pharmaceuticals, personal care products, phenolic endocrine disrupters and faecal steroids by GC/MS and PTV-GC/MS in environmental waters. Anal. Chim. Acta 2010, 658, 32-40. [CrossRef]

201. Azzouz, A.; Ballesteros, E. Science of the Total Environment Combined microwave-assisted extraction and continuous solid-phase extraction prior to gas chromatography-Mass spectrometry determination of pharmaceuticals, personal care products and hormones in soils, sediments and sludge. Sci. Total Environ. 2012, 419, 208-215. [CrossRef]

202. Huerta-fontela, M.; Teresa, M.; Ventura, F. Fast liquid chromatography-Quadrupole-linear ion trap mass spectrometry for the analysis of pharmaceuticals and hormones in water resources. J. Chromatogr. A 2010, 1217, 4212-4222. [CrossRef]

203. Grujic, S.; Vasiljevic, T.; Lausevic, M. Determination of multiple pharmaceutical classes in surface and ground waters by liquid chromatography-ion trap-tandem mass spectrometry. J. Chromatogr. A 2009, 1216, 4989-5000. [CrossRef]

204. Nödler, K.; Licha, T.; Bester, K.; Sauter, M. Development of a multi-residue analytical method, based on liquid chromatography-Tandem mass spectrometry, for the simultaneous determination of 46 micro-contaminants in aqueous samples. J. Chromatogr. A 2010, 1217, 6511-6521. [CrossRef] [PubMed]

205. Shao, B.; Chen, D.; Zhang, J.; Wu, Y.; Sun, C. Determination of 76 pharmaceutical drugs by liquid chromatography-tandem mass spectrometry in slaughterhouse wastewater. J. Chromatogr. A 2009, 1216, 8312-8318. [CrossRef] [PubMed]

206. Gracia-lor, E.; Sancho, J.V.; Hernández, F. Simultaneous determination of acidic, neutral and basic pharmaceuticals in urban wastewater by ultra high-pressure liquid chromatography-tandem mass spectrometry. J. Chromatogr. A 2010, 1217, 622-632. [CrossRef] [PubMed]

207. Lavén, M.; Alsberg, T.; Yu, Y.; Adolfsson-erici, M.; Sun, H. Serial mixed-mode cation-and anion-exchange solid-phase extraction for separation of basic, neutral and acidic pharmaceuticals in wastewater and analysis by high-performance liquid chromatography-Quadrupole time-of-flight mass spectrometry. J. Chromatogr. A 2009, 1216, 49-62. [CrossRef] [PubMed]

208. Al-odaini, N.A.; Pauzi, M.; Ismail, M.; Surif, S. Multi-residue analytical method for human pharmaceuticals and synthetic hormones in river water and sewage effluents by solid-phase extraction and liquid chromatography-Tandem mass spectrometry. J. Chromatogr. A 2010, 1217, 6791-6806. [CrossRef] [PubMed]

209. Yu, K.; Li, B.; Zhang, T. Direct rapid analysis of multiple PPCPs in municipal wastewater using ultrahigh performance liquid chromatography-Tandem mass spectrometry without SPE. Anal. Chim. Acta. 2012, 738, 59-68. [CrossRef] [PubMed]

210. Batt, A.L.; Kostich, M.S.; Lazorchak, J.M. Analysis of Ecologically Relevant Pharmaceuticals in Wastewater and Surface Analysis of Ecologically Relevant Pharmaceuticals in Wastewater and Surface Water Using Selective Solid-Phase Extraction and UPLC-MS/MS. Anal. Chem. 2008, 80, 5021-5030. [CrossRef] [PubMed]

211. Nieto, A.; Borrull, F.; Marc, R.M.; Pocurull, E. Selective extraction of sulfonamides, macrolides and other pharmaceuticals from sewage sludge by pressurized liquid extraction. J. Anal. Chem. 2007, 1174, 125-131. [CrossRef]

212. Ding, W.; Fann, J.C.H. Application of pressurized liquid extraction followed by gas chromatography-Mass spectrometry to determine 4-nonylphenols in sediments. J. Chromatogr. A 2000, 866, 79-85. [CrossRef]

213. Dabrowski, L.; Giergielewicz-mozajska, H.; Biziuk, M.; Gaca, J.; Namiesnik, J. Some aspects of the analysis of environmental pollutants in sediments using pressurized liquid extraction and gas chromatography-mass spectrometry. J. Chromatogr. A 2002, 957, 59-67. [CrossRef] 
214. Barron, L.; Tobin, J.; Paull, B. Multi-residue determination of pharmaceuticals in sludge and sludge enriched soils using pressurized liquid extraction, solid phase extraction and liquid chromatography with tandem. J. Environ. Monit. 2008, 10, 353-361. [CrossRef] [PubMed]

215. Osemwengie, L.I. Determination of synthetic musk compounds in sewage biosolids by gas chromatography/mass spectrometry. J. Environ. Monit. 2006, 8, 897-903. [CrossRef] [PubMed]

216. Mason, T.; Lorimer, J. Sonochemistry: Theory, Applications and Uses of Ultrasound in Chemistry; Ellis Horwood Publishers: Ford Road, Totnes, UK, 1989.

217. Salisova, M.; Toma, S.; Mason, T.J. Comparison of conventional and ultrasonically assisted extractions of pharmaceutically active compounds from Salvia officinalis. Ultrason. Chem. 1997, 4, 131-134.

218. Ebringerová, A.; Hromádková, Z. The effect of ultrasound on the structure and properties of the water-soluble corn hull heteroxylan. Ultrason. Sonochem. 1997, 74, 305-309. [CrossRef]

219. Vinatoru, M.; Toma, M.; Mason, T. Ultrasonically assisted extraction of bioactive principles from plants and the constituents. Adv. Sonochem. 1999, 5, 216.

220. Hromadkova, Z.; Ebringerova, A.; Valachovic, P. Comparison of classical and ultrasound-assisted extraction of polysaccharides from Salvia officinalis L. Ultrason. Sonochemistry 1999, 5, 163-168. [CrossRef]

221. Vinatoru, M. An overview of the ultrasonically assisted extraction of bioactive principles from herbs. Ultrason. Sonochem. 2001, 8, 303-313. [CrossRef]

222. Hromadkova, Z.; Ebiringerova, A.; Valachovi, P. Ultrasound-assisted extraction of water-soluble polysaccharides from the roots of valerian (Valeriana officinalis L.). Ultrason. Sonochem. 2002, 9, 37-44. [CrossRef]

223. Hromadkova, Z.; Ebringerova, A. Ultrasonic extraction of plant materials-Investigation of hemicellulose release from buckwheat hulls. Ultrason. Sonochem. 2003, 10, 127-133. [CrossRef]

224. Luque-Garcia, J.L.; De Castro, M.D.L. Ultrasound: A powerful tool for leaching. Trends Anal. Chem. 2003, 22, 41-47. [CrossRef]

225. Śliwiński, A. Ultrasound and Their Application; WNT: Warszawa, Poland, 2001.

226. Loning, J.; Horst, C.; Hoffmann, U. Investigations on the energy conversion in sonochemical processes. Ultrasonics 2002, 9, 169-179. [CrossRef]

227. Núnez, L.; Turiel, E.; Martin-Esteban, A.; Tadeo, J.L. Talanta Molecularly imprinted polymer for the extraction of parabens from environmental solid samples prior to their determination by high performance liquid chromatography-Ultraviolet detection. Talanta 2010, 80, 1782-1788. [CrossRef] [PubMed]

228. Sánchez-brunete, C.; Miguel, E.; Albero, B.; Tadeo, J.L. Analysis of salicylate and benzophenone-type UV filters in soils and sediments by simultaneous extraction cleanup and gas chromatography-Mass spectrometry. J. Chromatogr. A 2011, 1218, 4291-4298. [CrossRef] [PubMed]

229. Ferdig, M.; Kaleta, A.; Buchberger, W. Improved liquid chromatographic determination of nine currently used (fluoro) quinolones with fluorescence and mass spectrometric detection for environmental samples. J. Sep. Sci 2005, 28, 1448-1456. [CrossRef] [PubMed]

230. Nie, Y.; Qiang, Z.; Zhang, H.; Adams, C. Determination of endocrine-disrupting chemicals in the liquid and solid phases of activated sludge by solid phase extraction and gas chromatography-Mass spectrometry. J. Chromatogr. A 2009, 1216, 7071-7080. [CrossRef] [PubMed]

231. Lindberg, R.H.; Wennberg, P.; Johansson, I.M.; Tysklind, M.; Andersson, B.A.V. Screening of Human Antibiotic Substances and Determination of Weekly Mass Flows in Five Sewage Treatment Plants in Sweden. Environ. Sci. Technol. 2005, 39, 3421-3429. [CrossRef]

232. Zuloaga, O.; Navarro, P.; Bizkarguenaga, E.; Iparraguirre, A.; Vallejo, A.; Olivares, M.; Prieto, A. Analytica Chimica Acta Overview of extraction, clean-up and detection techniques for the determination of organic pollutants in sewage sludge: A review. Anal. Chim. Acta 2012, 736, 7-29. [CrossRef]

233. Mendiola, A.; Herrero, M.; Cifuentes, A.; Ibanez, E. Use of compressed fluids for sample preparation: Food applications. J. Chromatogr. A 2007, 1152, 234-246. [CrossRef]

234. Schantz, M.M. Pressurized liquid extraction in environmental analysis. Anal Bioanal Chem 2006, 386, 1043-1047. [CrossRef]

235. Farre, M.; Perez, S.; Carlos, G.; Alpendurada, M.; Barcelo, D. Green analytical chemistry in the determination of organic pollutants in the aquatic environment. Trends Anal. Chem. 2010, 29, 1347-1362. [CrossRef] 
236. Saleh, A.; Larsson, E.; Yamini, Y.; Åke, J. Hollow fiber liquid phase microextraction as a preconcentration and clean-up step after pressurized hot water extraction for the determination of non-steroidal anti-inflammatory drugs in sewage sludge. J. Chromatogr. A 2011, 1218, 1331-1339. [CrossRef] [PubMed]

237. Mudiam, R.K.M.; Jain, R.; Singh, R. Analytical Methods of phenolic endocrine disruptor chemicals in water samples by gas chromatography-triple quadrupole. Anal. Method 2014, 6, 1802-1810. [CrossRef]

238. Delgado, B.; Pino, V.; Anderson, J.L.; Ayala, J.H.; Afonso, A.M.; Gonzalez, V. An in-situ extraction-Preconcentration method using ionic liquid-based surfactants for the determination of organic contaminants contained in marine sediments. Talanta 2012, 99, 972-983. [CrossRef] [PubMed]

239. Bélanger, J.M.R.; Paré, J.R.J. Applications of microwave-assisted processes (MAP ${ }^{\mathrm{TM}}$ ) to environmental analysis. Anal. Bioanal. Chem 2006, 386, 1049-1058. [CrossRef] [PubMed]

240. Letellier, M.; Budzinski, H. Microwave assisted extraction of organic compounds. Analusis 1999, 27, $259-271$. [CrossRef]

241. García, N.D.; Gómez, A.Z.; Cantarero, S.; Navalón, A.; Vílchez, J.L. Simultaneous determination of 13 quinolone antibiotic derivatives in wastewater samples using solid-phase extraction and ultra performance liquid chromatography-Tandem mass spectrometry. Microchem. J. 2013, 106, 323-333. [CrossRef]

242. Eskilsson, C.S.; Bjorklund, E. Analytical-scale microwave-assisted extraction. J. Chromatogr. A 2000, 902, 227-250. [CrossRef]

243. Herrero, M.; Mendiola, J.A.; Cifuentes, A.; Ibánez, E. Supercritical fluid extraction: Recent advances and applications. J. Chromatogr. A 2010, 1217, 2495-2511. [CrossRef]

244. Bowadt, S.; Hawthorne, S. Supercritical fluid extraction.pdf. J. Chromatogr. A 1995, 703, 549-571. [CrossRef]

245. De Castro, M.D.l.; Priego-Capote, F. Soxhlet extraction: Past and present panacea. J. Chromatogr. A 2010, 1217, 2383-2389. [CrossRef]

246. Kupper, T.; De Alencastro, L.f.; Alencastro, D.; Gatsigazi, R.; Furrer, R.; Grandjean, D.; Tarradellas, J. Concentrations and specific loads of brominated flame retardants in sewage sludge. Chemosphere 2008, 71, 1173-1180. [CrossRef] [PubMed]

247. Cantarero, C.; Bengoechea, S. Analysis of Linear Alkylbenzene Sulfonate in Waste Water and Sludge by High Performance Liquid Chromatography: An Exercise of Validation. J. Surfact. Deterg. 2009, 12, 21-29.

248. Abad, E.; Martınez, K.; Planas, C.; Palacios, O.; Caixach, J.; Rivera, J. Priority organic pollutant assessment of sludges for agricultural purposes. Chemosphere 2005, 61, 1358-1369. [CrossRef] [PubMed]

249. Bester, K. Triclosan in a sewage treatment process-Balances and monitoring data. Water Res. 2003, 37, 3891-3896. [CrossRef]

250. Mitra, S. Sample Preparation Techniques in Analytical Chemistry; Winefordner, J., Ed.; John Wiley and Sons Inc.: Hoboken, NJ, USA, 2004; ISBN 3175723993.

251. Reddersen, K.; Heberer, T. Formation of an artifact of diclofenac during acidic extraction of environmental water samples. J. Chromatogr. A 2003, 1011, 221-226. [CrossRef]

252. Desbrow, C.; Routledge, E.; Brightly, G.C.; Sumpter, J.P.; Waldock, M. Identification of estrogenic chemicals in STW effluent. 1. Chemical fractionation and in vitro biological screening. Environ. Sci. Technol. 1998, 32, 1549-1558. [CrossRef]

253. Carpinteiro, J.; Quintana, J.B.; Rodr, I.; Carro, A.M.; Lorenzo, R.A.; Cela, R. Applicability of solid-phase microextraction followed by on-fiber silylation for the determination of estrogens in water samples by gas chromatography-Tandem mass spectrometry. J. Chromatogr. A 2004, 1056, 179-185. [CrossRef]

254. Barcelo, D. Applications of LC-MS in Environmental Chemistry; Barceló, D., Ed.; Elsevier: Amsterdam, The Netherlands, 1996; ISBN 9780080858678.

255. Liang, H.R.; Foltz, R.L.; Meng, M.; Bennett, P. Ionization enhancement in atmospheric pressure chemical ionization and suppression in electrospray ionization between target drugs and stable-isotope- labeled internal standards in quantitative liquid chromatography/tandem mass spectrometry. Rapid Commun. Mass Spectr. 2003, 17, 2815-2821. [CrossRef]

256. Mei, H.; Hsieh, Y.; Nardo, C.; Xu, X.; Wang, S.; Ng, K.; Korfmacher, W.A. Investigation of matrix effects in bioanalytical high-performance liquid chromatography/tandem mass spectrometric assays: Application to drug discovery. Rapid Commun. Mass Spectr. 2003, 17, 97-103. [CrossRef]

257. Diaz-Cruz, M.S.; Barcelo, D. LC-MS trace analysis of antimicrobials in water, sediment and soil. Trends Anal. Chem. 2005, 24, 645-657. [CrossRef] 
258. Altria, K.; Filbey, S. Quantitative pharmaceutical analysis by capillary electrophoresis. J. Liq. Chromatogr. 1993, 16, 0148-3919. [CrossRef]

259. Osbourn, D.M.; Weiss, D.J.; Lunte, C.E. Review On-line preconcentration methods for capillary electrophoresis CE and CEC. Electrophoresis 2000, 21, 2768-2779. [CrossRef]

260. Dawod, M.; Breadmore, M.C.; Guijt, R.M.; Haddad, P.R. Electrokinetic supercharging for on-line preconcentration of seven non-steroidal anti-inflammatory drugs in water samples. J. Chromatogr. A 2008, 1189, 278-284. [CrossRef] [PubMed]

261. Alshana, U.; Göger, N.G.; Ertas, N. Dispersive liquid-Liquid microextraction combined with field-amplified sample stacking in capillary electrophoresis for the determination of non-steroidal anti-inflammatory drugs in milk and dairy products. Food Chem. 2013, 138, 890-897. [CrossRef] [PubMed]

262. Ahrer, W.; Scherwenk, E.; Buchberger, W. Determination of drug residues in water by the combination of liquid chromatography or capillary electrophoresis with electrospray mass spectrometry. J. Chromatogr. A 2001, 910, 69-78. [CrossRef]

263. Amelin, V.G.; Bol'shakow, D.; Tretyakow, A. Separation and quantification of polar pesticides in well, surface, and drinking water by capillary electrophoresis. J. Anal. Chem. 2012, 67, 904-924. [CrossRef]

264. Zhong, S.; Ngin, S.; Ge, L.; Wang, W.; Chen, J. Talanta Determination of bisphenol A and naphthols in river water samples by capillary zone electrophoresis after cloud point extraction. Talanta 2011, 85, 488-492. [CrossRef] [PubMed]

265. Macia, A.; Borrull, F.; Calull, M.; Benavente, F.; Hernundez, E.; Sanz-Neboth, V.; Barbosa, J.; Aguila, C. Sensitivity enhancement for the analysis of naproxen in tap water by solid-phase extraction coupled in-line to capillary electrophoresis. J. Sep. Sci 2008, 31, 872-880. [CrossRef] [PubMed]

266. Hernández-Borges, J.; García-Montelongo, F.J.; Cifuentes, A.; Rodríguez-Delgado M, Á. Determination of herbicides in mineral and stagnant waters at ng/L levels using capillary electrophoresis and UV detection combined with solid-phase extraction and sample stacking. J. Chromatogr. A 2005, 1070, 171-177. [CrossRef] [PubMed]

267. Ramaswamy, B.R.; Shanmugam, G.; Velu, G.; Rengarajan, B.; Larsson, D.G.J. GC-MS analysis and ecotoxicological risk assessment of triclosan, carbamazepine and parabens in Indian rivers. J. Hazard. Mater. 2011, 186, 1586-1593. [CrossRef]

268. Suntornsuk, L. Recent advances of capillary electrophoresis in pharmaceutical analysis. Anal. Bioanal. Chem. 2010, 398, 29-52. [CrossRef] [PubMed]

269. Andreozzi, R.; Raffael, M.; Nicklas, P. Pharmaceuticals in STP effluents and their solar photodegradation in aquatic environment. Chemosphere 2003, 50, 1319-1330. [CrossRef]

270. Hawthorne, S.B.; Grabanski, C.B.; Martin, E.; Miller, D.J. Comparisons of Soxhlet extraction, pressurized liquid extraction, supercritical fluid extraction and subcritical water extraction for environmental solids: Recovery, selectivity and effects on sample matrix. J. Chromatogr. A 2000, 892, 421-433. [CrossRef]

271. Ene, A.; Bogdevich, O.; Sion, A. Science of the Total Environment Levels and distribution of organochlorine pesticides (OCPs) and polycyclic aromatic hydrocarbons (PAHs) in topsoils from SE Romania. Sci. Total Environ. 2012, 439, 76-86. [CrossRef] [PubMed]

272. Selvaraj, K.K.; Shanmugam, G.; Sampath, S.; Larsson, D.G.J.; Ramaswamy, R.B. Ecotoxicology and Environmental Safety GC-MS determination of bisphenol A and alkylphenol ethoxylates in river water from India and their ecotoxicological risk assessment. Ecotoxicol. Environ. Saf. 2014, 99, 13-20. [CrossRef] [PubMed]

273. Ribeiro, C.; Tiritan, M.E.; Rocha, E.; João, P.M. Development and Validation of a HPLC-DAD Method for Determination of Several Endocrine Disrupting Compounds in Estuarine Water. J. Liq. Chromatogr. Relat. Technol. 2007, 30, 2729-2746. [CrossRef]

274. Villar-navarro, M.; Ramos-payán, M.; Fernández-torres, R.; Callejón-mochón, M.; Bello-lópez, M.Á. A novel application of three phase hollow fiber based liquid phase microextraction (HF-LPME) for the HPLC determination of two endocrine disrupting compounds (EDCs), n-octylphenol and n-nonylphenol, in environmental waters. Sci. Total Environ. 2013, 443, 1-6. [CrossRef] [PubMed]

275. Fauzan, T.; Omar, T.; Ahmad, A.; Zaharin, A. Trends in Analytical Chemistry Endocrine disrupting compounds (EDCs) in environmental matrices: Review of analytical strategies for pharmaceuticals, estrogenic hormones, and alkylphenol compounds. Trends Anal. Chem. 2016, 85, 241-259. 
276. Petrovic, M.; Barcelo, D. Liquid chromatography-Mass spectrometry in the analysis of emerging environmental contaminants. Anal. Bioanal. Chem. 2006, 385, 422-424. [CrossRef]

277. Buchberger, W.W. Novel analytical procedures for screening of drug residues in water, waste water, sediment and sludge. Anal. Chim. Acta 2007, 593, 129-139. [CrossRef]

278. American Chemical Society. Environmental Science and Technology; CODEN; ESTHAG; American Chemical Society: Washington, DC, USA, 2013; Volume 47, pp. 3439-3447, ISSN 00139-36X.

(C) 2019 by the authors. Licensee MDPI, Basel, Switzerland. This article is an open access article distributed under the terms and conditions of the Creative Commons Attribution (CC BY) license (http://creativecommons.org/licenses/by/4.0/). 